\title{
Growth kinetics, fatty acid composition and metabolic activity changes of Crypthecodinium cohnii under different nitrogen source and concentration
}

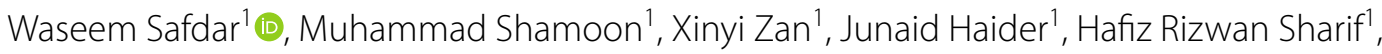 \\ Muhammad Shoaib ${ }^{1}$ and Yuanda Song ${ }^{1,2^{*}}$
}

\begin{abstract}
The effect of varying concentrations of the nitrogen source on the growth kinetics, lipid accumulation, lipid and DHA productivity, and fatty acid composition of C. cohnii was elucidated. Growth of C. cohnii was in three distinct growth stages: cell growth, lipid accumulation and a final lipid turnover stage. Most of lipids were accumulated in lipid accumulation stage (48-120 h) though, slow growth rate was observed during this stage. $\mathrm{NaNO}_{3}$ supported significantly higher lipid content (26.9\% of DCW), DHA content $(0.99 \mathrm{~g} / \mathrm{L})$ and DHA yield ( $44.2 \mathrm{mg} / \mathrm{g}$ glucose) which were 2.5 to 3.3-folds higher than other $\mathrm{N}$-sources. The maximum level of C16-C18 content (\% TFA) was calculated as 43,54 and $43 \%$ in lipid accumulation stage under low nitrogen ( $(L N, 0.2 \mathrm{~g} / \mathrm{L})$, medium nitrogen $(\mathrm{MN}, 0.8 \mathrm{~g} / \mathrm{L})$ and high nitrogen $(\mathrm{HN}, 1.6 \mathrm{~g} / \mathrm{L})$ treatments, respectively. Cultures with $\mathrm{LN}$, by down-regulating cell metabolism, trigger onset of lipogenic enzymes. Conversely, $\mathrm{NAD}^{+} / \mathrm{NADP}^{+}$-dependent isocitrate dehydrogenase $\left(\mathrm{NAD}^{+} / \mathrm{NADP}^{+}-\mathrm{ICDH}\right)$ were less active in $\mathrm{LN}$ than $\mathrm{HN}$ treatments which resulted in retardation of Kreb's Cycle and thereby divert citrate into cytoplasm as substrate for ATP-citrate lyase (ACL). Thereby, ACL and fatty acid synthase (FAS) were most active in lipid accumulation stage at LN treatments. Glucose-6-phosphate dehydrogenase (G6PDH) was more active than malic enzyme (ME) in lipid accumulation stage and showed higher activities in $\mathrm{NaNO}_{3}$ than other $\mathrm{N}$-sources. This represents that G6PDH contributes more NADPH than ME in C. cohnii. However, G6PDH and ME together seems to play a dual role in offering NADPH for lipid biosynthesis. This concept of ME together with G6PD in offering NADPH for lipogenesis might be novel in this alga and needed to be explored.
\end{abstract}

Keywords: Crypthecodinium cohnii, N-sources, lipid accumulation, DHA, G6PDH, ATP:citrate lyase

\section{Introduction}

Crypthecodinium cohnii is a heterotrophic dinoflagellate that has been used for the commercial production of oil rich in docosahexaenoic acid (DHA, 22:6 n-3) since mid 1990s. DHA-rich oil form C. cohnii is simple in Fatty acid profile, cost effective and without typical fishy smell

\footnotetext{
*Correspondence: ysong@sdut.edu.cn

${ }^{2}$ Colin Ratledge Center for Microbial Lipids, School of Agriculture Engineering and Food Science, Shandong University of Technology, Zibo 255049, Shandong, People's Republic of China

Full list of author information is available at the end of the article
}

(Wynn et al. 2005). Many of studies were reported evaluating the effect of nutrients and factors such as glucose, carbon, culture temperature, salinity and light etc. for lipid production in C. cohnii (DeSwaaf et al. 2003; Gong et al. 2015; Liu et al. 2015; Liu et al. 2016a, b; Pleissner and Eriksen 2012; Ratledge et al. 2001; Silva et al. 2016; Sun et al. 2017). In resent researches, the effect of $N$ has been positively exploited in Monoraphidium sp. (Dhup and Dhawan 2014), Scenedesmus abundans (GonzálezGarcinuño et al. 2014), Saccharomyces cerevisiae (Portugal-Nunes et al. 2017), S. rubescens (Lin and Lin 2011) 
and Stigeoclonium sp. (Liu et al. 2016a, b) for the production of commercially important lipids.

As $\mathrm{N}$ plays a pivotal role for the synthesis of both protein and nucleic acid and an increased in $\mathrm{N}$ supply profoundly enhanced their production which, otherwise, ceased when culture becomes N-limited. This directly relates with biomass reduction and hence, increases lipids (Ratledge and Wynn 2002). Batch fermentation methodologies offer essential experimental settings and result in lowered biomass yield, facilitating the higher lipid accumulation via maintaining enclosed $\mathrm{N}$-starved environment. N-limitation in culture condition stimulated lipid accumulation in oleaginous microorganisms (Ratledge 2014; Zhao et al. 2015). It is also widely accepted that most oleaginous microorganisms start accumulating lipids in presence of excess carbon and limited N-sources in the medium (Ikaran et al. 2015; Lv et al. 2010; Ördög et al. 2016). However, the final algal biomass production typically depends on strain capacity and fermentation strategy which may exceed as high as $100 \mathrm{~g} / \mathrm{L}$ DCW in ideal conditions (Gaffney et al. 2014).

Astoundingly, there is only one report about glutamic acid (as $\mathrm{N}$-source) limitation cause reduction in growth with no significant effect on specific lipid contents of C. cohnii CCMP 316 (Pleissner and Eriksen 2012). To our knowledge, there is no other experimental evidence elaborating the influence of other $\mathrm{N}$-sources (nitrates and ammonium) on cell growth and lipid accumulation in C. cohnii. Therefore, present study was aimed to explore the effects of different $\mathrm{N}$-sources and concentrations on biochemical and physiological changes in C. cohnii. Furthermore, the role of $\mathrm{N}$ influence on metabolic activities of key enzymes; fatty acid synthase (FAS), malic enzyme (ME), ATP citrate lyase (ACL), glucose 6-phosphate dehydrogenase (G6PDH), citrate synthase (CS), $\mathrm{NADP}^{+}$-dependent isocitrate dehydrogenase $\left(\mathrm{NADP}^{+}-\mathrm{ICDH}\right)$ and $\mathrm{NAD}^{+}$-dependent isocitrate dehydrogenase $\left(\mathrm{NAD}^{+}-\mathrm{ICDH}\right)$ was also elucidated in regulating the lipid accumulation. Our work provides comprehensive understanding of lipid accumulation and new insights which may prove promising for the effective lipid enhancement and particularly DHA production in C. cohnii.

\section{Materials and methods}

\section{Microorganism and culture conditions}

Crypthecodinium cohnii (ATCC 30555) was purchased from the America Type Culture Collection (ATCC) and maintained in sterilized ATCC460 medium. Batch cultures were performed in $5 \mathrm{~L}$ fermenters (NBS Bioflo 115, USA) with $10 \%(\mathrm{v} / \mathrm{v})$ inoculum size and $3 \mathrm{~L}$ working volume. The inocula were grown in ATCC 460 A2E6 medium for three days in a $500 \mathrm{~mL}$ flask before centrifugation and re-suspension in optimized experimental medium composed of $(\mathrm{g} / \mathrm{L}): \mathrm{NaCl}, 23.5 ; \mathrm{Na}_{2} \mathrm{SO}_{4}, 3.9 ; \mathrm{NaHCO}_{3}, 0.2$; $\mathrm{MgCl}_{2} \cdot 6 \mathrm{H}_{2} \mathrm{O}, 10.6 ; \mathrm{KCl}, 0.7 ; \mathrm{CaCl}_{2}, 1.1 ; \mathrm{KBr}, 0.1$; glucose, 27; disodium glycerophosphate, 15; glutamic acid, 0.2; tris, 3; $\mathrm{SrCl}_{2} \cdot 6 \mathrm{H}_{2} \mathrm{O}, 0.04 ; \mathrm{K}_{2} \mathrm{HPO}_{4}, 0.1 ; 5.0 \mathrm{~mL}$ of metal mixture $(\mathrm{g} / \mathrm{L})$ : $\left(\mathrm{Na}_{2} \mathrm{EDTA}, 10 ; \mathrm{FeCl}_{3} \cdot 6 \mathrm{H}_{2} \mathrm{O}, 0.5 ; \mathrm{H}_{3} \mathrm{BO}_{3}\right.$, 10; $\left.\mathrm{MnCl}_{2} \cdot 4 \mathrm{H}_{2} \mathrm{O}, 1.6 ; \mathrm{CoCl}_{2} \cdot 6 \mathrm{H}_{2} \mathrm{O}, 0.005\right) ; \mathrm{ZnCl}_{2}, 0.1$; $1.0 \mathrm{~mL}$ vitamin solution $(\mathrm{mg} / \mathrm{L})$ : (Biotin, 3; Thiamine, 1000 ), and $\mathrm{N}$-source. Different concentrations (indicated in the text) of $\left(\mathrm{NH}_{4}\right)_{2} \mathrm{SO}_{4},\left(\mathrm{NH}_{2}\right)_{2} \mathrm{CO}, \mathrm{NH}_{4} \mathrm{HCO}_{3}$ and $\mathrm{NaNO}_{3}$ were used as $\mathrm{N}$-sources.

Initial $\mathrm{pH}$ was adjusted to 6.5 and controlled at this value by automatic addition of $2 \mathrm{M} \mathrm{HCl}$ and $2 \mathrm{M} \mathrm{KOH}$. Stepwise dissolved oxygen tension was achieved by shifting agitation speed from 700 to $300 \mathrm{rpm}$. Foaming was controlled by automatic addition of $5 \%(\mathrm{w} / \mathrm{v})$ silicone SE-2. The medium inside the fermenters were sterilized by autoclaving at $121{ }^{\circ} \mathrm{C}$ for $20 \mathrm{~min}$. All fine chemicals were purchased from Sigma-Aldrich unless otherwise. Three replicates were performed in all experiments.

\section{Determination of physiological parameters}

Biomass concentration, from daily harvested $50-100 \mathrm{~mL}$ samples, was determined gravimetrically by centrifugation $\left(10 \mathrm{~min}, 3000 \times g\right.$ for $\left.5{ }^{\circ} \mathrm{C}\right)$. Briefly, the cell pellet was rinsed twice with distilled water, frozen overnight at $-80{ }^{\circ} \mathrm{C}$ and weighted following the lyophilisation for $24 \mathrm{~h}$. Biomass concentration was expressed as dry cell weight $(\mathrm{DCW})$ per liter. The biomass productivity $\left(P_{\mathrm{DCW}}\right)$ was calculated using Eq. 1.

$$
P_{\mathrm{DCW}}(\mathrm{g} / \mathrm{L} \text { day })=\frac{\mathrm{DCW}_{\mathrm{f}}-\mathrm{DCW}_{\mathrm{i}}}{\mathrm{T}_{\mathrm{f}}-\mathrm{T}_{\mathrm{i}}}
$$

where $\mathrm{DCW}_{\mathrm{f}}$ final biomass content $(\mathrm{g} / \mathrm{L})$; $\mathrm{T}_{\mathrm{f}}$ harvesting time (day); $\mathrm{DCW}_{\mathrm{i}}$ : initial biomass production $(\mathrm{g} / \mathrm{L}) ; \mathrm{T}_{\mathrm{i}}$ : cultivation time (day).

Indophenol method (Chaney and Marbach 1962) was used to determine ammonium concentration in the culture. Glucose concentration in the culture was measured using glucose oxidase Perid-test kit (Shanghai Rongsheng Biotech Co., Ltd). Soluble phosphate was determined using colorimetric method (Ren et al. 2013). Absorbance of the supernatant was measured at $885 \mathrm{~nm}$, after proper dilution with deionized water. Phosphate concentration was determined by using a calibration curve made with $\mathrm{KH}_{2} \mathrm{PO}_{4}$ in the range 10-70 $\mu \mathrm{M}$. Nitrate concentration in the culture medium was determined spectrophotometrically according to the method described by Collos et al. (1999). Briefly, culture samples were daily harvested, centrifuged $\left(3000 \times g, 5{ }^{\circ} \mathrm{C}\right.$ for $\left.10 \mathrm{~min}\right)$ and supernatant was collected. The absorbance was measured at $220 \mathrm{~nm}$ after a proper dilution with deionized water (Ikaran et al. 2015). The absorbance values were converted to 
nitrate concentration using a standard calibration curve made with $\mathrm{NaNO}_{3}$ in the range $0-10 \mathrm{mM}$. As lipid accumulation completely ceased at $\mathrm{N}$-source concentration above $20 \mathrm{mM}$, therefore treatment above this value was excluded from the analysis.

\section{Determination of fatty acid composition}

Lipids were extracted by a modified protocol of Bligh and Dyer (1959) from freeze-dried cells. The lipid productivity $\left(P_{\text {Lipid }}\right)$ and DHA productivity $\left(P_{\text {DHA }}\right)$ were calculated by following formulae 2 and 3 :

$$
\begin{aligned}
& P_{\text {Lipid }}(\mathrm{g} / \mathrm{L} \text { day })=\frac{C_{\mathrm{f}} \times \mathrm{DCW}_{\mathrm{f}}-C_{\mathrm{i}} \times \mathrm{DCW}_{\mathrm{i}}}{\mathrm{T}_{\mathrm{f}}-\mathrm{T}_{\mathrm{i}}} \\
& P_{\text {DHA }}(\mathrm{g} / \mathrm{L} \text { day })=\frac{C_{\mathrm{DHA}}(\mathrm{g} / \mathrm{g} \mathrm{TL}) \times \operatorname{Lipid}(\mathrm{g} / \mathrm{L})}{\text { Time }(\text { day })}
\end{aligned}
$$

where $C_{f}$ : final lipid content $(g / L)$; $C_{i}$ : initial lipid content; TL: total lipid.

For fatty acid (FA) analysis, $\sim 100 \mathrm{mg}$ of lyophilized algal biomass was re-suspended in $5 \mathrm{~mL}$ chloroform: methanol $(2: 1 \mathrm{v} / \mathrm{v})$ containing pentadecanoic acid (15:0, $2.0 \mathrm{mg} / \mathrm{mL}$; Sigma) as an internal standard and $0.5 \mathrm{mg} /$ $\mathrm{mL}$ butylated hydroxytoluene (BHT) as an antioxidant at room temperature for $24 \mathrm{~h}$. After centrifugation $(5 \mathrm{~min}$, $3000 \times g$ ), the supernatant containing extracted lipids were transferred into a clean tube and residue was resuspended in chloroform: methanol $(2: 1 \mathrm{v} / \mathrm{v})$ at room temperature for $12 \mathrm{~h}$. After centrifugation, supernatants from both extractions were combined and washed with $2 \mathrm{~mL}$ of saturated $\mathrm{NaCl}$. The resultant fatty acid methyl esters (FAMEs) were extracted in hexane and analyzed by gas chromatography (GC-2010; Shimadzu Co., Kyoto, Japan). GC was equipped with a capillary DB-WAX column ( $30 \mathrm{~m} \times 0.32 \mathrm{~mm}$, ठ $0.25 \mu \mathrm{m}$, Agilent, USA) and FID detector; helium was the carrier gas. The oven temperature was initially held at $120{ }^{\circ} \mathrm{C}$ for $3 \mathrm{~min}$ and raised to $180^{\circ} \mathrm{C}$ by increasing $5^{\circ} \mathrm{C}$ per min, then raised to $260^{\circ} \mathrm{C}$ at the rate $5{ }^{\circ} \mathrm{C}$ per min, and finally held at $260^{\circ} \mathrm{C}$ for $5 \mathrm{~min}$. The FAs were identified with standards (Sigma, USA). Three biological replicates were performed in all experiments and analyzed using a one-way analysis of variance (ANOVA) analysis using SPSS Statistics 19.

\section{Determination of enzyme activities Preparation of cell-free enzyme extracts}

Biomass, periodically harvested by centrifugation from the fermenters, was washed twice with washing buffer (200 mM Tris/HCl, pH 7.4, 2 mM DTT and 1 mM EDTA) and re-suspended in the same buffer. After being ultrasonically (Scientz-II D sonifier) disrupted at $225 \times 4 \mathrm{~s}$ with cooling in between on ice for $15 \mathrm{~min}$, the cell suspensions were centrifuged $\left(10,000 \times g ; 10 \mathrm{~min}\right.$ at $\left.4{ }^{\circ} \mathrm{C}\right)$. The supernatant containing cytoplasmic and mitochondrial enzymes was subjected to enzyme activity analysis. Standard Bradford method was used to determine the protein concentration.

\section{Enzyme activity analysis}

Activities of fatty acid synthase (FAS), malic enzyme (ME), ATP:citrate lyase (ACL), glucose-6-phosphate dehydrogenase (G6PDH), citrate synthase (CS), $\mathrm{NADP}^{+}$-dependent isocitrate dehydrogenase $\left(\mathrm{NADP}^{+}-\mathrm{ICDH}\right)$ and $\mathrm{NAD}^{+}$-dependent isocitrate dehydrogenase $\left(\mathrm{NAD}^{+}-\mathrm{ICDH}\right)$ were determined in supernatant fraction by continuous spectrophotometric assays at $30{ }^{\circ} \mathrm{C}$. For FAS analysis, the reaction mixture contained 0.3\% (w/v) BSA, $4 \mathrm{mM} \mathrm{DTT,} 100 \mathrm{mM} \mathrm{KH_{2 }} \mathrm{PO}_{4} /$ $\mathrm{KOH}$ ( $\mathrm{pH}$ 6.5), $0.18 \mathrm{mM}$ acetyl-CoA, $2.5 \mathrm{mM}$ EDTA, $0.09 \mathrm{mM}$ malonyl-CoA, $0.14 \mathrm{mM} \mathrm{NADPH}$ and cell free extract. The reaction mixture for $\mathrm{ME}$ analysis contained $25 \mathrm{mM}$ malate, $3 \mathrm{mM} \mathrm{MgCl} 2,80 \mathrm{mM} \mathrm{KH}_{2} \mathrm{PO}_{4} / \mathrm{KOH}(\mathrm{pH}$ 7.5), $0.6 \mathrm{mM} \mathrm{NADP}^{+}$and cell free extract; the reaction was initiated by adding $25 \mathrm{mM}$ malate. For ACL analysis, the reaction mixture contained $0.3 \mathrm{mg} \mathrm{CoA} / \mathrm{mL}, 10 \mathrm{mM}$ sodium azide, $10 \mathrm{mM}$ Tris/HCl ( $\mathrm{pH}$ 8.6), $0.2 \mathrm{mM} \mathrm{NADH,}$ $10 \mathrm{mM}$ mercaptoethanol, 5 units malate dehydrogenase/ ml, 5 mM ATP (pH 7.5) and cell free extract. For G6PDH analysis, the reaction mixture contained $0.3 \mathrm{mM} \mathrm{NADP}^{+}$, $5 \mathrm{mM} \mathrm{MgCl} 2,50 \mathrm{mM}$ Tris/HCl pH 8.0, $2.5 \mathrm{mM}$ glucose 6-phosphate and cell free extract. For CS analysis, the reaction mixture contained cell free extract, $0.12 \mathrm{mM}$ acetyl-CoA, $0.2 \mathrm{mM}$ oxaloacetate, $400 \mathrm{mM}$ Tris/HCl $(\mathrm{pH} 8.0)$ and $0.25 \mathrm{mM}$ DTNB. NADP ${ }^{+}-\mathrm{ICDH}$ activity was assayed as described by Wynn et al. (1999) and $\mathrm{NAD}^{+}$-ICDH activity was assayed as described by Wynn et al. (2001). For ME, G6PD and CS an increase in OD was measured at $30 \mathrm{~s}$. For ACL and FAS, a decrease in $\mathrm{OD}$ was measured at $30 \mathrm{~s}$. An interval of $3 \mathrm{~min}$ at $340 \mathrm{~nm}$ was given for each enzyme. One unit of enzyme activity (U) was defined as "the amount of enzyme, required to produce 1 mol enzymatic reaction product in $1 \mathrm{~min}$ in the above mentioned conditions". The protein concentration in the cell free extract was determined by standard Bradford method. Three biological replicates were used for each enzyme activity to assess reproducibility.

\section{Results}

Effect of different $\mathrm{N}$-sources on $\mathrm{C}$. cohnii Growth kinetics and lipid accumulation

The time-course profile of cell growth and lipid accumulation of C. cohnii cultured for 7 days under the influence of different $\mathrm{N}$-sources is given in Fig. 1. A particular pattern of growth and lipid accumulation was observed in C. cohnii during the entire growth period. Rapid cell 

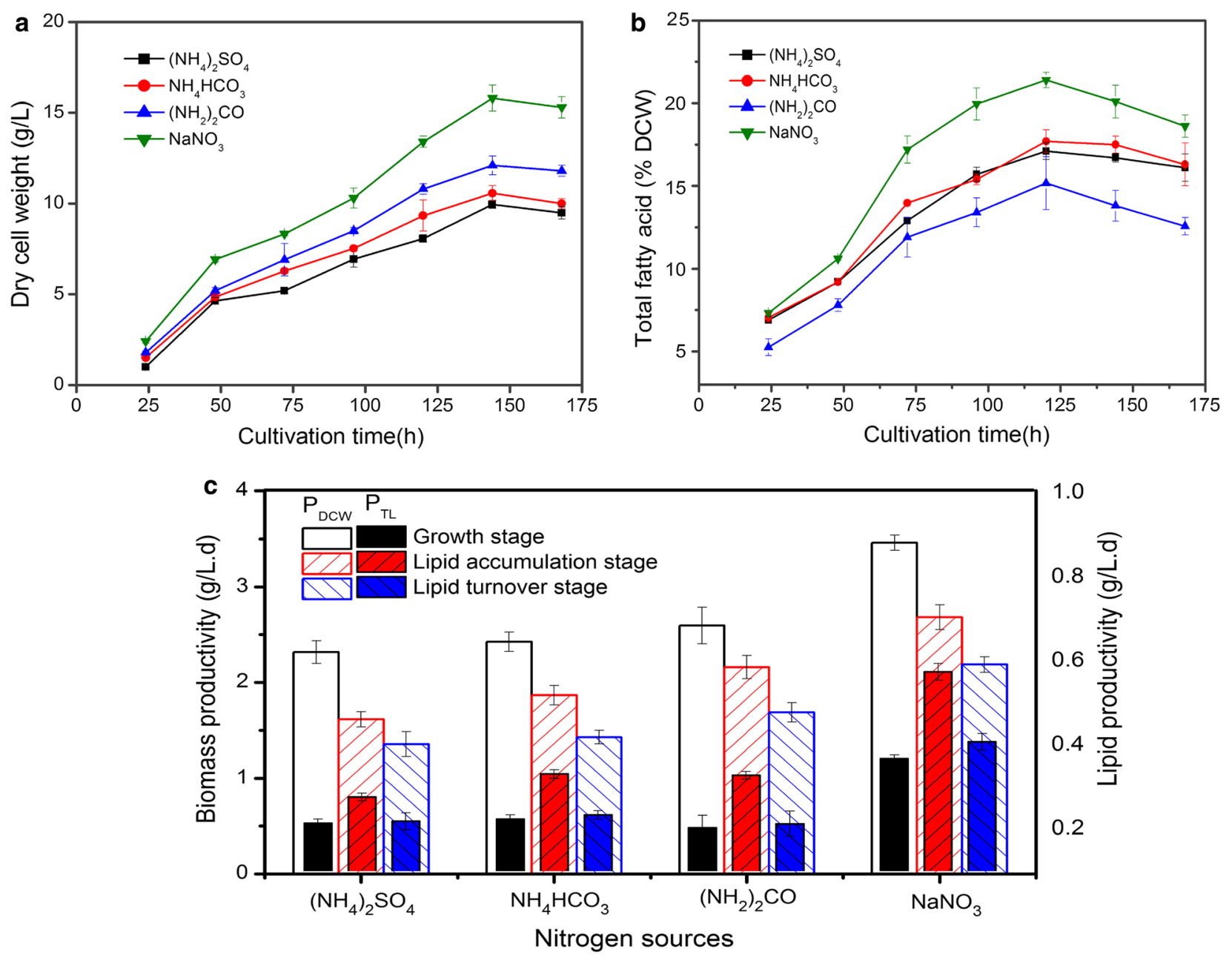

Fig. 1 The time-course profile of cell growth and lipid accumulation in C. Cohnii under different N-sources. a Dry cell weight (DCW, g/L), b total fatty acid (TFA, \% DCW) of C. cohnii for cultured for 7 days. c Biomass productivity $\left(P_{D C w}, g / L\right.$ day) and lipid productivity $\left(P_{T L}, g / L\right.$ day) of $C$. Cohnii grown on different $\mathrm{N}$-sources at three different growth stages. All experiments were performed in triplicate. The data presented here is mean $\pm \mathrm{SD}$

growth was observed from 0 to $48 \mathrm{~h}$ when there is a sufficient supply of $\mathrm{N}$ and glucose; this was identified as "cell growth stage". After $48 \mathrm{~h}$, a continuous but slower growth was noticed throughout the remaining culture time (Fig. 1a). Compared to ammonium sulphate, ammonium bicarbonate and urea, the biomass (DCW) with sodium nitrate supplementation was significantly higher and reached up to the highest level of $15.82 \pm 0.72 \mathrm{~g} / \mathrm{L}$ at $144 \mathrm{~h}$ of cultivation. Simultaneously, ammonium sulphate and ammonium bicarbonate can support almost similar growth pattern of C. cohnii under the investigated conditions which is however lower than urea (Fig. 1a).

After $48 \mathrm{~h}$, when cell growth slowed, lipids commence to accumulate till $120 \mathrm{~h}$ as long as there was sufficient carbon source (above $4.5 \mathrm{~g} / \mathrm{L}$ ) in culture mediums and identified as "Lipid accumulation stage". Maximum lipid content was obtained at $120 \mathrm{~h}$ of cultivation in all treatments. Highest level of total lipid (\% DCW) was accumulated $21.4 \pm 0.5 \%$ in $\mathrm{NaNO}_{3}$ treatment (Fig. 1b). In contrary with the biomass, urea showed the lowest lipid accumulation rate $(10.7 \mathrm{mg} / \mathrm{L} \mathrm{h})$ as compared to $\left(\mathrm{NH}_{4}\right)_{2} \mathrm{SO}_{4}(12.7 \mathrm{mg} / \mathrm{L} \mathrm{h})$ and $\mathrm{NH}_{4} \mathrm{HCO}_{3}(12.3 \mathrm{mg} / \mathrm{L} \mathrm{h})$ in lipid accumulation stage. Whereas, $\mathrm{NaNO}_{3}$ showed the highest lipid accumulation rate $(21.73 \mathrm{mg} / \mathrm{L} \mathrm{h})$ which was 1.9 folds higher than that in the growth stage $(11.3 \mathrm{mg} / \mathrm{L}$ h). After $120 \mathrm{~h}$, lipid accumulation ceased and lipid turnover occurred from 120 to $168 \mathrm{~h}$ and identified as "lipid turnover stage". Similar trend of lipid accumulation was also observed in treatment with other $\mathrm{N}$-sources. There was a significant difference in cell growth and lipid accumulation when cultured on different $\mathrm{N}$-sources $(P<0.05)$. Along with biomass, lipid productivity is also 
important to evaluate the overall performance of microalgae. Maximum biomass productivity ( $3.5 \mathrm{~g} / \mathrm{L}$ day) and lipid productivity $(0.6 \mathrm{~g} / \mathrm{L}$ day $)$ was obtained with $\mathrm{NaNO}_{3}$ (Fig. 1c).

Figure 2 shows the time-course profile of substrates depletion (glucose, nitrate and phosphorus) by C. cohnii. As expected, the uptake rate of glucose and nitrate in $\mathrm{NaNO}_{3}$ supplemented medium was significantly higher than others. However, there was no significant difference in phosphorus assimilation in the cultures treated with different $\mathrm{N}$-sources $(P<0.05)$. Conversely, the assimilation rate of glucose in $\mathrm{NaNO}_{3}$ supplemented medium gradually decreased from cell growth stage $(0.36 \pm 0.05 \mathrm{~g} / \mathrm{L} \mathrm{h})$ to lipid accumulation $(0.22 \pm 0.09 \mathrm{~g} / \mathrm{L}$ h) and followed by lipid turnover stage $(0.14 \pm 0.06 \mathrm{~g} / \mathrm{L}$ h). Similar trend was observed with nitrate and phosphate (Fig. 2). Lipid yield at the cost of glucose assimilated (mg/g GLC) was also calculated (Table 1). Results showed that highest lipid yield was obtained when grown on $\mathrm{NaNO}_{3}(130.3 \pm 4.5 \mathrm{mg} / \mathrm{g}$ GLC) in lipid accumulation stage which was 3.4 folds higher than that in growth stage.

\section{Fatty acid shifts in the three growth stages}

Fatty acid profile was presented in three growth stages of microalgae under the influence of different $\mathrm{N}$-sources (Fig. 3). Regarding the fatty acid composition, one of the primary goals of this study was to increase DHA (C22:6n3) content in C. cohnii. The highest DHA content was attained in lipid turnover stage $(35.7 \pm 1.3 \%$ TFA $)$ with a slight difference from lipid accumulation stage $\left(34.8 \pm 0.9 \%\right.$ TFA) under $\mathrm{NaNO}_{3}$ which was $32-44 \%$ higher than that of $\mathrm{NH}_{4} \mathrm{HCO}_{3}$ (Table 1). Similar results were found in newly isolated Crypthecodinium sp. SUN, which yielded $34.1 \pm 0.3 \%$ TFA at $120 \mathrm{~h}$ and $35.0 \pm 0.2 \%$ TFA at $144 \mathrm{~h}$ under light (Sun et al. 2017). For comparison, the overall DHA productivity, as well as yield (per gram of glucose exhaustion) during three growth stages is given in Table 1. It was obvious that $\mathrm{NaNO}_{3}$ supported significantly higher DHA content $(0.99 \pm 0.05 \mathrm{~g} / \mathrm{L})$, DHA productivity $(193.84 \pm 2.76 \mathrm{mg} / \mathrm{L}$ day $)$ and DHA yield (44.16 $\pm 3.64 \mathrm{mg} / \mathrm{g}$ glucose) which were 2.1 to 2.8 -folds higher than other $\mathrm{N}$-sources $(P<0.001)$.

Compared to DHA, in growth stage palmitic acid (C16:0) was produced at the highest percentage
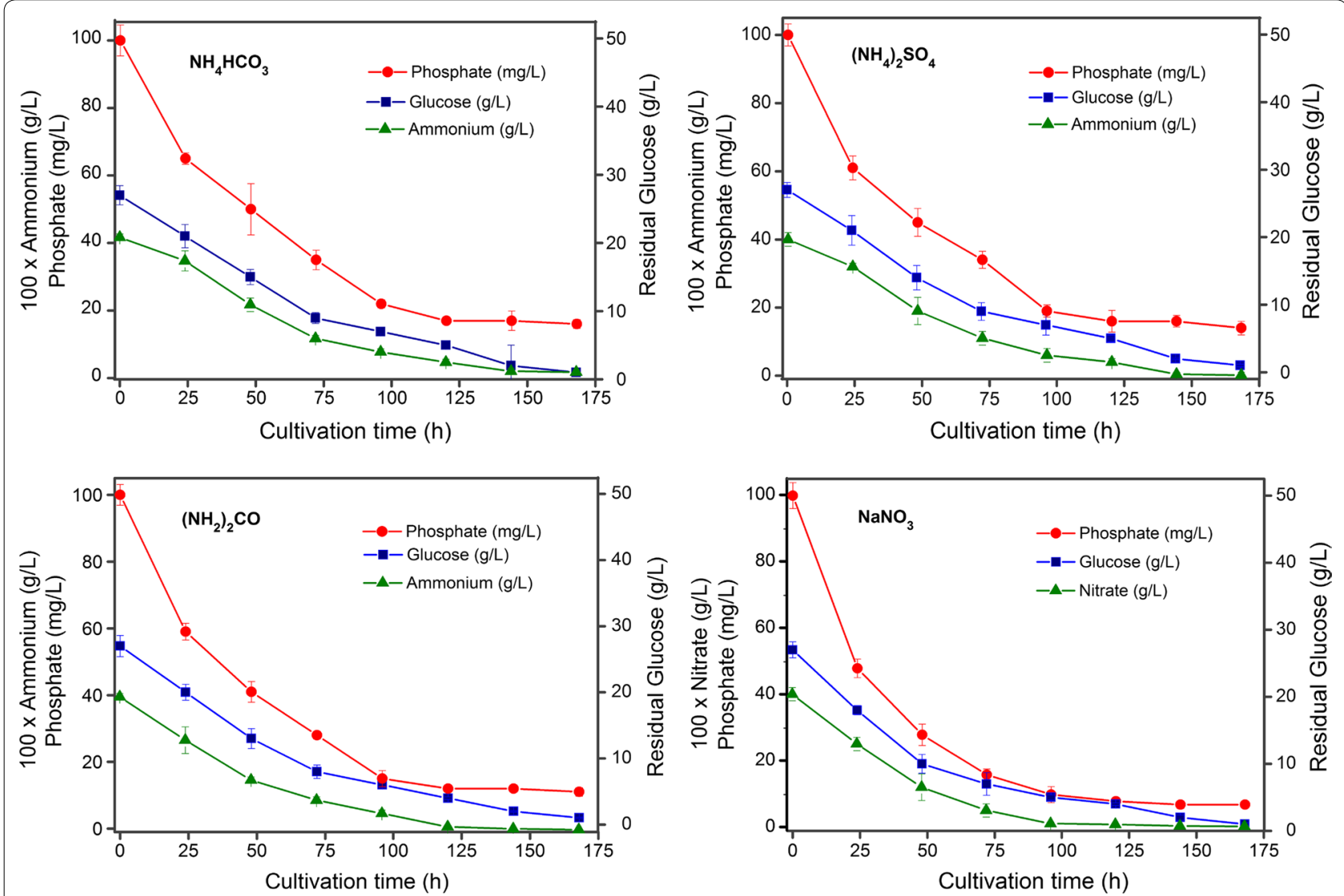

Fig. 2 The time-course profile of residual substrates (glucose, nitrate and phosphorus) concentration in C. cohnii cultured on different nitrogen sources for 7 days. All experiments were performed in triplicate. The data presented here is mean \pm SD 
Table 1 Comparison of DHA content, DHA productivity, lipid and DHA yield of C. cohnii under different N-sources

\begin{tabular}{|c|c|c|c|c|c|}
\hline $\mathrm{N}$-source & Growth stage & $\mathrm{C}_{\mathrm{DHA}}(\mathrm{g} / \mathrm{L})$ & $P_{D H A}(m g / L$ day) & $\mathrm{Y}_{\mathrm{L}}^{\mathrm{a}}(\mathrm{mg} / \mathrm{g} \mathrm{GLC})$ & $Y_{D H A}^{a}(m g / g ~ G L C)$ \\
\hline \multirow{3}{*}{$\left(\mathrm{NH}_{4}\right)_{2} \mathrm{SO}_{4}$} & Growth & $0.05 \pm 0.0$ & $22.4 \pm 4.9$ & $35.5 \pm 2.2$ & $3.7 \pm 0.7$ \\
\hline & Lipid accumulation & $0.35 \pm 0.1$ & $70.9 \pm 8.9$ & $65.6 \pm 1.4$ & $16.9 \pm 2.5$ \\
\hline & Lipid turnover & $0.42 \pm 0.1$ & $60.3 \pm 7.1$ & $71.3 \pm 5.3$ & $19.7 \pm 1.5$ \\
\hline \multirow{3}{*}{$\mathrm{NH}_{4} \mathrm{HCO}_{3}$} & Growth & $0.05 \pm 0.0$ & $25.8 \pm 1.6$ & $28.9 \pm 4.2$ & $3.9 \pm 1.2$ \\
\hline & Lipid accumulation & $0.39 \pm 0.08$ & $77.3 \pm 3.9$ & $74.4 \pm 1.1$ & $17.6 \pm 0.4$ \\
\hline & Lipid turnover & $0.43 \pm 0.05$ & $60.7 \pm 4.4$ & $66.8 \pm 3.5$ & $19.1 \pm 1.5$ \\
\hline \multirow[t]{3}{*}{$\left(\mathrm{NH}_{2}\right)_{2} \mathrm{CO}$} & Growth & $0.06 \pm 0.0$ & $27.5 \pm 3.1$ & $34.3 \pm 6.9$ & $4.2 \pm 1.5$ \\
\hline & Lipid accumulation & $0.46 \pm 0.05$ & $91.1 \pm 3.2$ & $75.1 \pm 2.2$ & $20.7 \pm 0.6$ \\
\hline & Lipid turnover & $0.46 \pm 0.11$ & $65.3 \pm 4.2$ & $73.4 \pm 3.4$ & $20.6 \pm 0.9$ \\
\hline \multirow[t]{3}{*}{$\mathrm{NaNO}_{3}$} & Growth & $0.13 \pm 0.02$ & $63.4 \pm 1.6$ & $43.1 \pm 3.5$ & $7.4 \pm 1.4$ \\
\hline & Lipid accumulation & $0.97 \pm 0.12$ & $193.8 \pm 2.8$ & $130.3 \pm 4.5$ & $44.1 \pm 3.6$ \\
\hline & Lipid turnover & $0.99 \pm 0.05$ & $141.1 \pm 5.7$ & $127.1 \pm 9.6$ & $44.1 \pm 2.4$ \\
\hline
\end{tabular}

All experiments were performed in triplicate. The data presented here is mean \pm SD

$C_{D H A}$ DHA content, $P_{D H A}$ DHA productivity (g/L day), $Y_{L}$ lipid yield (mg/g glucose), $Y_{D H A}$ DHA yield (g/g glucose)

a Yield was calculated on basis of glucose utilized

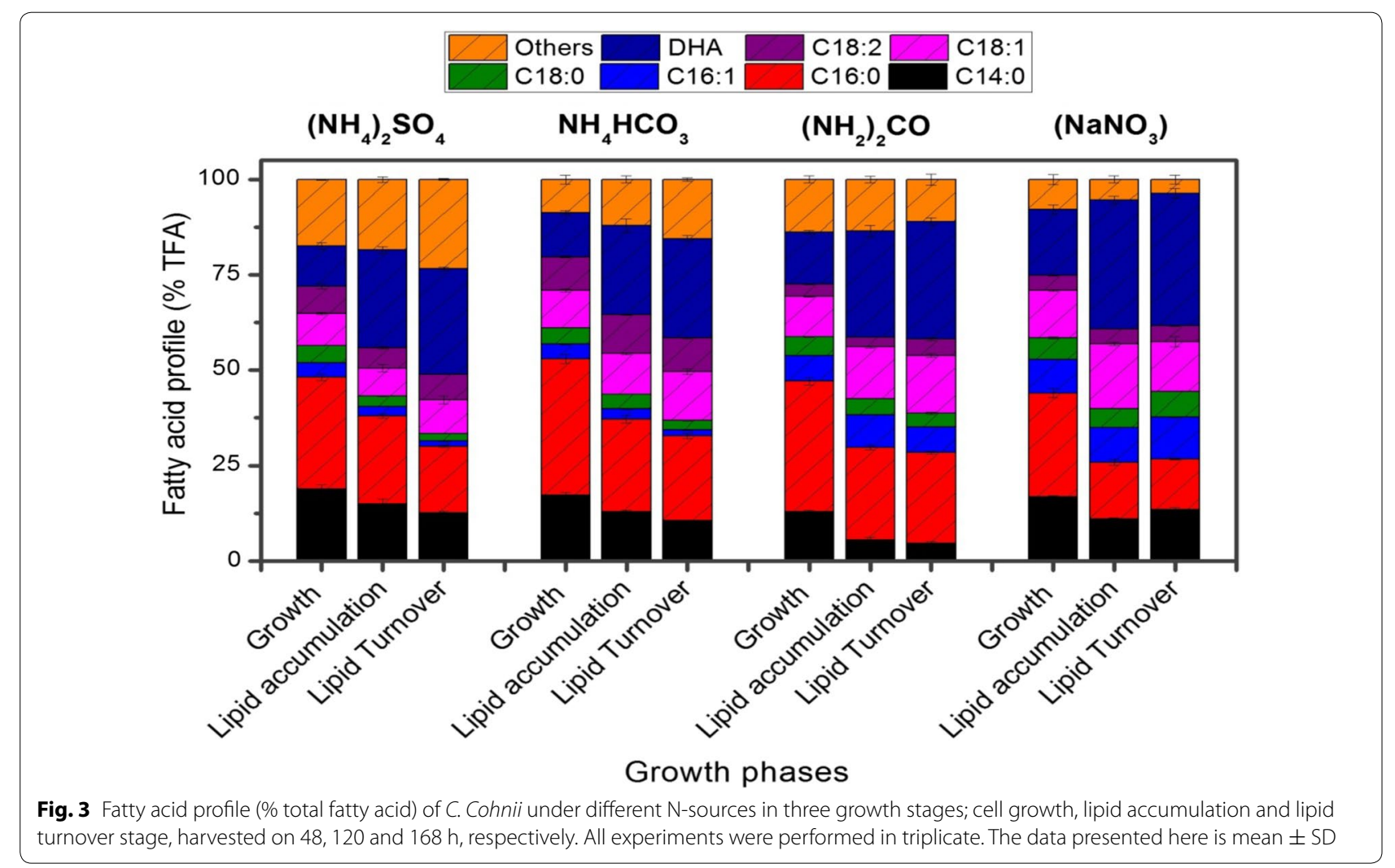

(27.2-35.7\% TFA) among all fatty acids in all treatments. A gradual decline was observed in saturated fatty acids (SFAs) myristic acid (C14:0), C16:0 and stearic acid (C18:0) in all the four treatments throughout the cultivation time (Fig. 3). In contrast, mono-unsaturated fatty acids (MUFAs) palmitoleic acid (C16:1) and oleic acid
(C18:1), increased during lipid accumulation stage and again decreased in lipid turnover stage in all treatments while no significant change was observed in Linoleic acid (C18:2n6) content (\% TFA) (Fig. 3). Combined C16C18 content (\% TFA) was calculated as $53.1,62.5,59.7$, $58.1 \%$ in cell growth stage and $51.9,54.7,53.1,49.8 \%$ in 
lipid accumulation stage under $\left(\mathrm{NH}_{4}\right)_{2} \mathrm{SO}_{4}, \mathrm{NH}_{4} \mathrm{HCO}_{3}$, $\left(\mathrm{NH}_{2}\right)_{2} \mathrm{CO}, \mathrm{NaNO}_{3}$ treatments, respectively (Fig. 3). Apparently, there is no significant difference in C16C18 content in lipid accumulation stage under different $\mathrm{N}$-sources; nevertheless, lowest $\mathrm{C} 16-\mathrm{C} 18$ content under $\mathrm{NaNO}_{3}$ might be due to highest DHA production. Presence of more than $50-60 \%$ of $\mathrm{C} 16-\mathrm{C} 18$ content in TFA suggested that $C$. cohnii can be considered as potential source for biodiesel production (Fig. 3).

\section{Effect of different nitrogen concentration Growth kinetics and lipid accumulation}

To investigate an optimal N-supply for growth and lipid accumulation of C. cohnii, different concentrations (0.2, $0.4,0.8,1.2,1.6 \mathrm{~g} / \mathrm{L})$ of $\mathrm{NaNO}_{3}$ supplementation were scrutinized. Figure 4 illustrates the effect of different concentrations of $\mathrm{NaNO}_{3}$ on dry cell weight (DCW) and lipid accumulation. Rapid cell growth was observed from 0 to $48 \mathrm{~h}$ when there is a sufficient supply of $\mathrm{N}$ and glucose (Fig. 4a). Comparable biomass yield $(0.3 \mathrm{~g} / \mathrm{g}$ glucose) was obtained at $24 \mathrm{~h}$ of cultivation in all $\mathrm{NaNO}_{3}$ treatments. After $36 \mathrm{~h} \mathrm{~N}$ was completely consumed in the control culture supplemented with $0.2 \mathrm{~g} / \mathrm{L} \mathrm{NaNO}_{3}$ and growth was restricted. Consequently, during the remaining 5 days, cells were $\mathrm{N}$-starved (Fig. $4 \mathrm{~d}$ ). In contrast, cells grown on other concentrations $(0.4,0.8,1.2,1.6 \mathrm{~g} / \mathrm{L})$ of $\mathrm{NaNO}_{3}$ displayed continuous but slower growth throughout the remaining culture time. From Fig. 4a and $\mathrm{d}$, it is noticeably obvious that algal growth was linearly correlated with $\mathrm{N}$ supply to a certain level and then show negative impact (decline).

As shown in Fig. 4a, growth was robustly improved with increasing concentration from 0.2 to $1.2 \mathrm{~g} / \mathrm{L}$ and beyond this a negative impact on cell growth was noticed. The final biomass content at high nitrogen $(\mathrm{HN}, 1.6 \mathrm{~g} / \mathrm{L})$ concentration was $83.7 \%$ lesser than that of medium nitrogen (MN, $0.8 \mathrm{~g} / \mathrm{L}$ ) supplemented culture. Both, the biomass concentration $(23.7 \pm 0.61 \mathrm{~g} / \mathrm{L})$ and biomass productivity $(5.10 \pm 0.19 \mathrm{~g} / \mathrm{L}$ day $)$ reached the highest values with $0.8 \mathrm{~g} / \mathrm{L} \mathrm{NaNO}_{3}$ treatment (Fig. 4a; Table 2). The highest growth rate was also obtained when cultured on $0.8 \mathrm{~g} / \mathrm{L} \mathrm{NaNO}_{3}(212 \mathrm{mg} / \mathrm{L} \mathrm{h})$ which was $53 \%$ higher
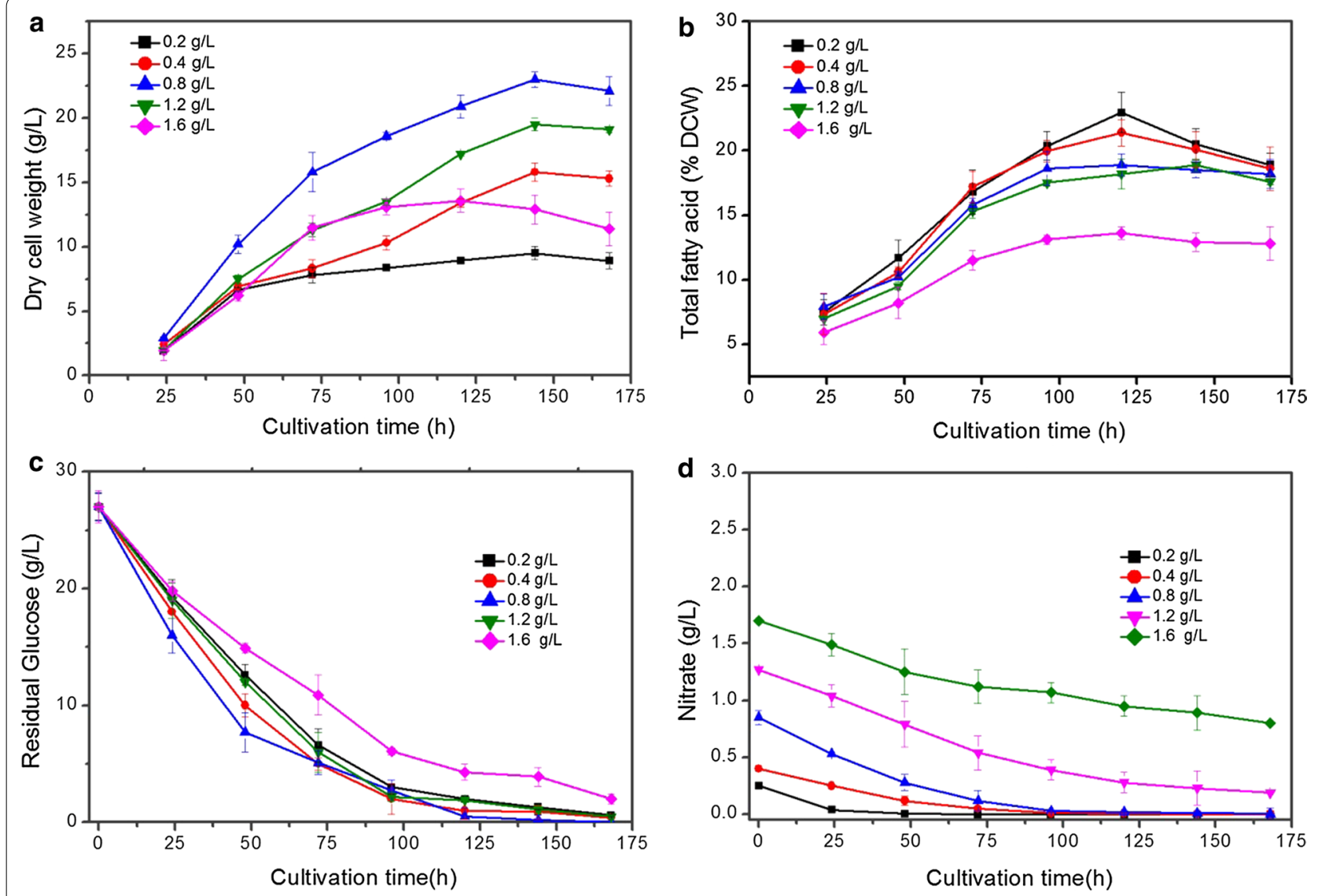

Fig. 4 Comparison of biomass and lipid content of $\mathrm{C}$. cohnii cultured on different $\mathrm{NaNO}_{3}$ concentrations. a The time-course profile of dry cell weight (DCW), b total fatty acid (TFA, \% DCW), c residual glucose (GLC) concentration and $\mathbf{d}$ residual nitrate concentration grown on different concentration of $\mathrm{NaNO}_{3}$ for 7 days. All experiments were performed in triplicate. The data presented here is mean \pm SD 
Table 2 Comparison of biomass yield, DHA content, DHA productivity, lipid and DHA yield of C. cohnii under different concentrations of $\mathrm{NaNO}_{3}$

\begin{tabular}{|c|c|c|c|c|c|c|c|}
\hline $\mathrm{NaNO}_{3}$ conc. & Time & $Y_{D C W}^{a}(g / g$ GLC) & $P_{L}(g / L$ day $)$ & $Y_{L}^{a}(m g / g ~ G L C)$ & $C_{D H A}(g / L)$ & $P_{D H A}(g / L$ day $)$ & $Y_{D H A}^{a}(m g / g ~ G L C)$ \\
\hline \multirow[t]{3}{*}{$0.2 \mathrm{~g} / \mathrm{L}$} & Growth & $0.46 \pm 0.032$ & $0.38 \pm 0.009$ & $54.05 \pm 3.1$ & $0.13 \pm 0.004$ & $0.064 \pm 0.000$ & $9.01 \pm 0.09$ \\
\hline & Lipid accumulation & $0.47 \pm 0.05$ & $0.48 \pm 0.01$ & $126.76 \pm 17.9$ & $0.91 \pm 0.008$ & $0.18 \pm 0.001$ & $47.83 \pm 2.19$ \\
\hline & Lipid turnover & $0.43 \pm 0.063$ & $0.28 \pm 0.02$ & $95.54 \pm 14.9$ & $0.78 \pm 0.009$ & $0.11 \pm 0.001$ & $38.12 \pm 4.72$ \\
\hline \multirow[t]{3}{*}{$0.4 \mathrm{~g} / \mathrm{L}$} & Growth & $0.40 \pm 0.007$ & $0.37 \pm 0.06$ & $43.14 \pm 8.98$ & $0.13 \pm 0.002$ & $0.063 \pm .002$ & $7.46 \pm 1.99$ \\
\hline & Lipid accumulation & $0.60 \pm 0.009$ & $0.57 \pm 0.03$ & $130.35 \pm 21.6$ & $0.96 \pm 0.088$ & $0.194 \pm 0.004$ & $44.05 \pm 11.5$ \\
\hline & Lipid turnover & $0.68 \pm 0.03$ & $0.41 \pm 0.01$ & $127.11 \pm 19.5$ & $0.99 \pm 0.08$ & $0.141 \pm 0.006$ & $44.10 \pm 8.55$ \\
\hline \multirow[t]{3}{*}{$0.8 \mathrm{~g} / \mathrm{L}$} & Growth & $0.52 \pm 0.008$ & $0.57 \pm 0.02$ & $53.90 \pm 7.25$ & $0.18 \pm 0.004$ & $0.089 \pm 0.04$ & $9.27 \pm 1.24$ \\
\hline & Lipid accumulation & $0.92 \pm 0.01$ & $0.79 \pm 0.002$ & $175.56 \pm 21.9$ & $1.18 \pm 0.01$ & $0.236 \pm 0.002$ & $52.49 \pm 5.52$ \\
\hline & Lipid turnover & $0.96 \pm 0.04$ & $0.62 \pm 0.006$ & $174.88 \pm 14.9$ & $1.29 \pm 0.02$ & $0.181 \pm 0.001$ & $56.14 \pm 2.16$ \\
\hline \multirow[t]{3}{*}{$1.2 \mathrm{~g} / \mathrm{L}$} & Growth & $0.5 \pm 0.008$ & $0.35 \pm 0.06$ & $47.5 \pm 4.69$ & $0.11 \pm 0.04$ & $0.055 \pm 0.000$ & $7.36 \pm 1.25$ \\
\hline & Lipid accumulation & $0.85 \pm 0.057$ & $0.63 \pm 0.008$ & $155.74 \pm 8.55$ & $0.66 \pm 0.03$ & $0.132 \pm 0.007$ & $33.01 \pm 7.27$ \\
\hline & Lipid turnover & $0.87 \pm 0.061$ & $0.48 \pm 0.02$ & $154.2 \pm 5.92$ & $0.72 \pm 0.006$ & $0.103 \pm 0.002$ & $33.30 \pm 9.68$ \\
\hline \multirow[t]{3}{*}{$1.6 \mathrm{~g} / \mathrm{L}$} & Growth & $0.51 \pm 0.024$ & $0.25 \pm 0.004$ & $42.01 \pm 7.91$ & $0.08 \pm 0.001$ & $0.038 \pm 0.000$ & $6.38 \pm 165$ \\
\hline & Lipid accumulation & $0.76 \pm 0.084$ & $0.36 \pm 0.009$ & $104.5 \pm 13.62$ & $0.33 \pm 0.002$ & $0.065 \pm 0.000$ & $18.39 \pm 3.52$ \\
\hline & Lipid turnover & $0.61 \pm 0.062$ & $0.21 \pm 0.03$ & $78.87 \pm 8.46$ & $0.26 \pm 0.06$ & $0.037 \pm 0.005$ & $14.19 \pm 2.88$ \\
\hline
\end{tabular}

All experiments were performed in triplicate. The data presented here is mean \pm SD

$Y_{D C W}$ growth yield (g/g glucose), $P_{L}$ lipid productivity (g/L day), $Y_{L}$ lipid yield (mg/g glucose), $C_{D H A}$ DHA content, $P_{D H A}$ biomass productivity (g/L day), $Y_{D H A}$ DHA yield (g/g glucose)

a Yield calculated on basis of glucose utilized

than that from low nitrogen $(\mathrm{LN}, 0.2 \mathrm{~g} / \mathrm{L})$ at $48 \mathrm{~h}$ of cultivation.

In the culture, when cells were $\mathrm{N}$-starved, a progressive increase in total fatty acid was observed from 48 to $120 \mathrm{~h}$ and reached up to $22.9 \pm 1.6 \%$ of DCW which was almost similar to that of MN, however, $70 \%$ higher than that of $\mathrm{HN}$ supply (Fig. 4b). Indeed, N-starvation does not influence lipid production, however, maximum lipid content $(4.3 \pm 0.17 \mathrm{~g} / \mathrm{L})$, lipid productivity $(0.79 \pm 0.01 \mathrm{~g} / \mathrm{L}$ day $)$ and lipid yield (175.56 $\pm 21.9 \mathrm{mg} / \mathrm{g}$ glucose) was obtained with MN supplementation (Table 2). Time course profile of substrates depletion by $C$. cohnii at different concentrations of $\mathrm{NaNO}_{3}$ is given in Fig. $4 \mathrm{c}$ and d. All substrates (glucose, nitrate and phosphorus) were assimilated rapidly within $48 \mathrm{~h}$ after inoculation and then became slow gradually until the end of the culture period. Complimenting with growth, the uptake rate of glucose and nitrate in the $\mathrm{MN}$ medium was significantly higher than in $\mathrm{HN}$ and LN medium however, no significant difference was noticed in case of phosphate consumption $(P<0.05)$. In LN medium since protein biosynthesis was limited, this leads to restricted growth rate, however no significant effect on glucose utilization was observed (Fig. 4c). Highest yields of residual glucose $8.5 \pm 0.9 \mathrm{~g} / \mathrm{L}$, phosphate $11.6 \pm 1.3 \mathrm{mg} / \mathrm{L}$ and nitrate $0.8 \pm 0.003 \mathrm{~g} / \mathrm{L}$ was acquired in $\mathrm{HN}$ supplemented culture compared to phosphate $10.9 \mathrm{mg} / \mathrm{L}$, glucose $2.5 \pm 0.5 \mathrm{~g} / \mathrm{L}$ and no detectable nitrogen in LN and MN cultures after $144 \mathrm{~h}$ (Fig. 4c, d).

\section{Fatty acid composition}

The fatty acids composition of C. cohnii under the influence of different $\mathrm{NaNO}_{3}$ concentrations is shown in Fig. 5. The predominant FA in all treatments was DHA $(40.5 \pm 0.52 \%$ TFA $)$. In this study, DHA content was negatively influenced by $\mathrm{NaNO}_{3}$ concentrations. At HN treatment, DHA content was $(18.5 \pm 0.39 \%$ TFA $)$ declined by $115 \%$ as compared to $\mathrm{LN}$ and MN treatment. Fatty acids present at moderate levels, as a percentage of the total FA, were C14:0 (16.8 $\pm 0.28 \%)$, C16:0 $(27.21 \pm 1.26 \%)$ and $\mathrm{C} 18: 1(12.39 \pm 0.27 \%)$ in MN treatment (Fig. 5). Despite of obtaining high levels of total fatty acids and DHA content at LN supplementation, biomass content was relatively low, which reduced the overall lipid productivity by $66 \%$ from $\mathrm{MN}$ treatment (Table 2). DHA yield was $32.9 \%$ lower in LN than HN supplementation (Table 2).

Saturated fatty acids (C14:0, C16:0 and C18:0) linearly decline from growth stage to lipid accumulation stage and then remained constant in lipid turnover stage in all $\mathrm{N}$-treatments. In contrast, mono-unsaturated fatty acids (C16:1 and C18:1) increased during lipid accumulation stage and again slightly reduced in lipid turnover stage while polyunsaturated fatty acids robustly increased till end of the cultivation time. The maximum level of C16C18 content (\% TFA) was calculated as 43.88, 54.13 and $43.67 \%$ in lipid accumulation stage under LN, MN and 


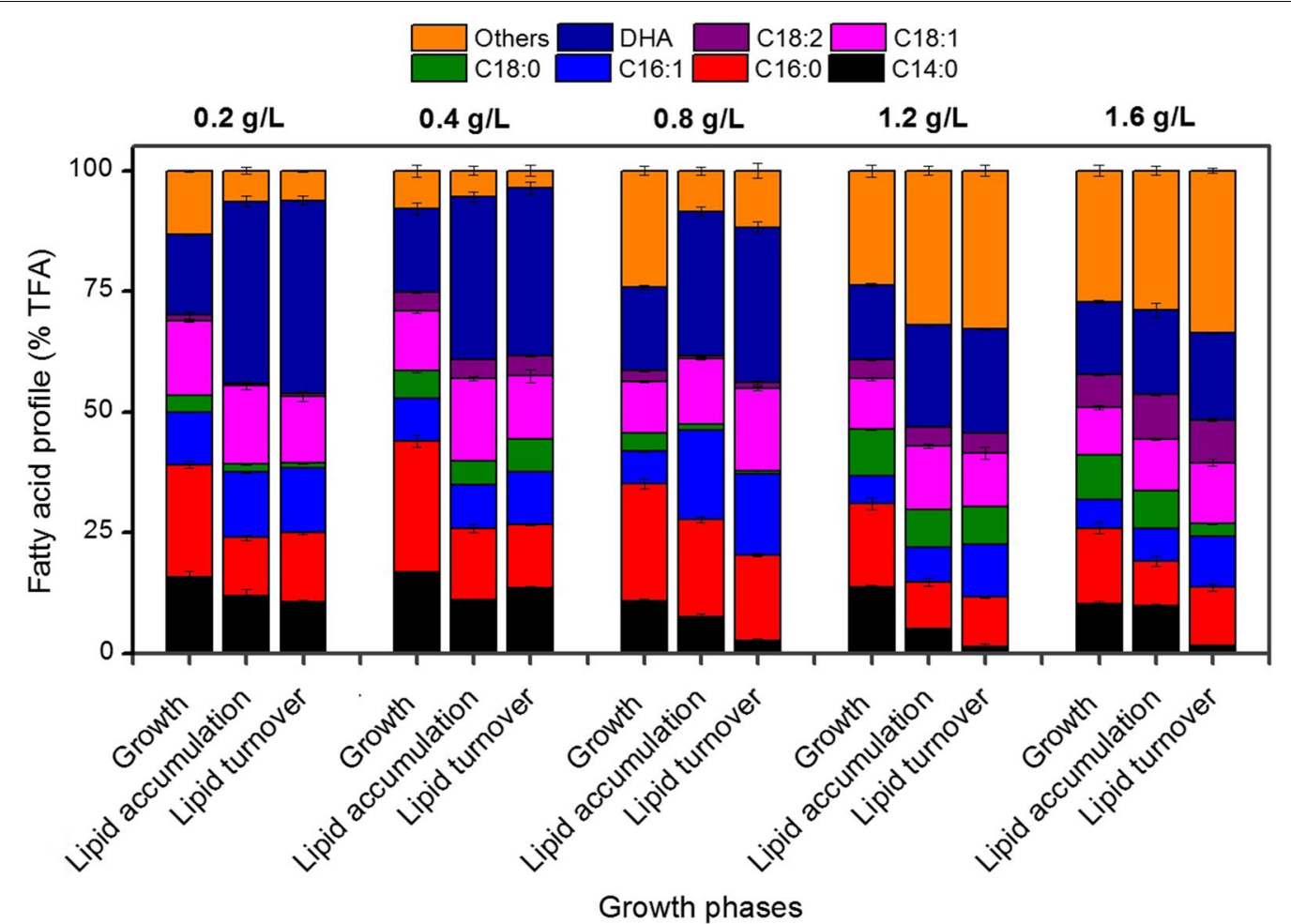

Fig. 5 Fatty acid profile of $\mathrm{C}$. cohnii under different $\mathrm{NaNO}_{3}$ concentration in three growth stages; cell growth, lipid accumulation and lipid turnover stage harvested on 48,120 and $168 \mathrm{~h}$, respectively. All experiments were performed in triplicate. The data presented here is mean \pm SD

HN treatments, respectively (Fig. 5). This highest C16C18 content was obtained under MN.

\section{Metabolic activity changes during lipid accumulation}

Figure 6 shows the metabolic pathway of fatty acid biosynthesis in oleaginous microorganisms. To compare the activity of key enzymes under $\mathrm{N}$-sources during identified growth stages (growth stage, lipid accumulation stage and lipid turnover stage) samples were taken at 48 , 120 and $168 \mathrm{~h}$, respectively. The specific activities of FAS, ME, ACL G6PDH, NADP ${ }^{+}-\mathrm{ICDH}, \mathrm{CS}$ and $\mathrm{NAD}^{+}-\mathrm{ICDH}$ were determined spectrophotometrically in each sample, the results are summarised in Tables 3 and 4. A gradual decline in the activities of $\mathrm{G} 6 \mathrm{PDH}, \mathrm{ME}, \mathrm{NADP}^{+}-\mathrm{ICDH}$, $\mathrm{CS}$ and $\mathrm{NAD}^{+}-\mathrm{ICDH}$ were detected from cell growth stage to lipid accumulation stage and followed to lipid turnover stage with lowest activities. Most probably this decline is triggered by substrate depletion particularly glucose in the culture. In contrast, FAS and ACL were the most active in lipid accumulation stage due to their direct role in lipid biosynthesis (Table 3 ). In this study, as $\mathrm{NaNO}_{3}$ supplementation engendered the highest growth and lipid accumulation, the activity of these lipogenic enzymes except CS correlates with our above results (Table 3).
In present study, ACL activity was higher under $\mathrm{NaNO}_{3}$ than other $\mathrm{N}$-sources which coincide with higher lipid production by providing more acetyl-CoA as substrate. While, $\left(\mathrm{NH}_{4}\right)_{2} \mathrm{SO}_{4}$ showed the lowest lipid accumulation, exhibit reduced ACL activity by $30 \%$ as compared to $\mathrm{NaNO}_{3}$. Similar tendency was observed for FAS which catalyze the fatty acid synthesis and thus, its activity directly associate with lipid accumulation. Our results also showed that ACL and FAS activities were inversely correlate with $\mathrm{NaNO}_{3}$ concentrations in medium as both were most active in lipid accumulation stage at $\mathrm{N}$-starved conditions $(85.9 \pm 2.8$ and $168.2 \pm 5.5 \mathrm{nmol} / \mathrm{min} \mathrm{mg}$ protein, respectively) which were 58 and $31.5 \%$ higher than $1.6 \mathrm{~g} / \mathrm{L} \mathrm{NaNO}_{3}(51.1 \pm 2.4,127.9 \pm 1.8 \mathrm{nmol} / \mathrm{min}$ mg protein, respectively) (Table 4 ). The activities of $\mathrm{ME}$ and G6PDH were higher in $\mathrm{NaNO}_{3}$ than $\left(\mathrm{NH}_{4}\right)_{2} \mathrm{SO}_{4}$ culture, which were 40 and $86 \%$ higher in growth stage; 85 and 93\% higher in lipid accumulation stage, respectively (Table 3).

$\mathrm{NADP}^{+}$-ICDH activity was significantly decreased from cell growth stage to lipid accumulation stage in all treatments $(\mathrm{P}<0.05)$. In lipid accumulation stage, $\mathrm{NaNO}_{3}$ showed $147 \%$ low $\mathrm{NADP}^{+}-\mathrm{ICDH}$ activity $(168.6 \pm 8.9 \mathrm{nmol} / \mathrm{min} \mathrm{mg}$ protein $)$ than $\left(\mathrm{NH}_{4}\right)_{2} \mathrm{SO}_{4}$ $(417.3 \pm 3.1 \mathrm{nmol} / \mathrm{min} \mathrm{mg}$ protein). Correspondingly, 


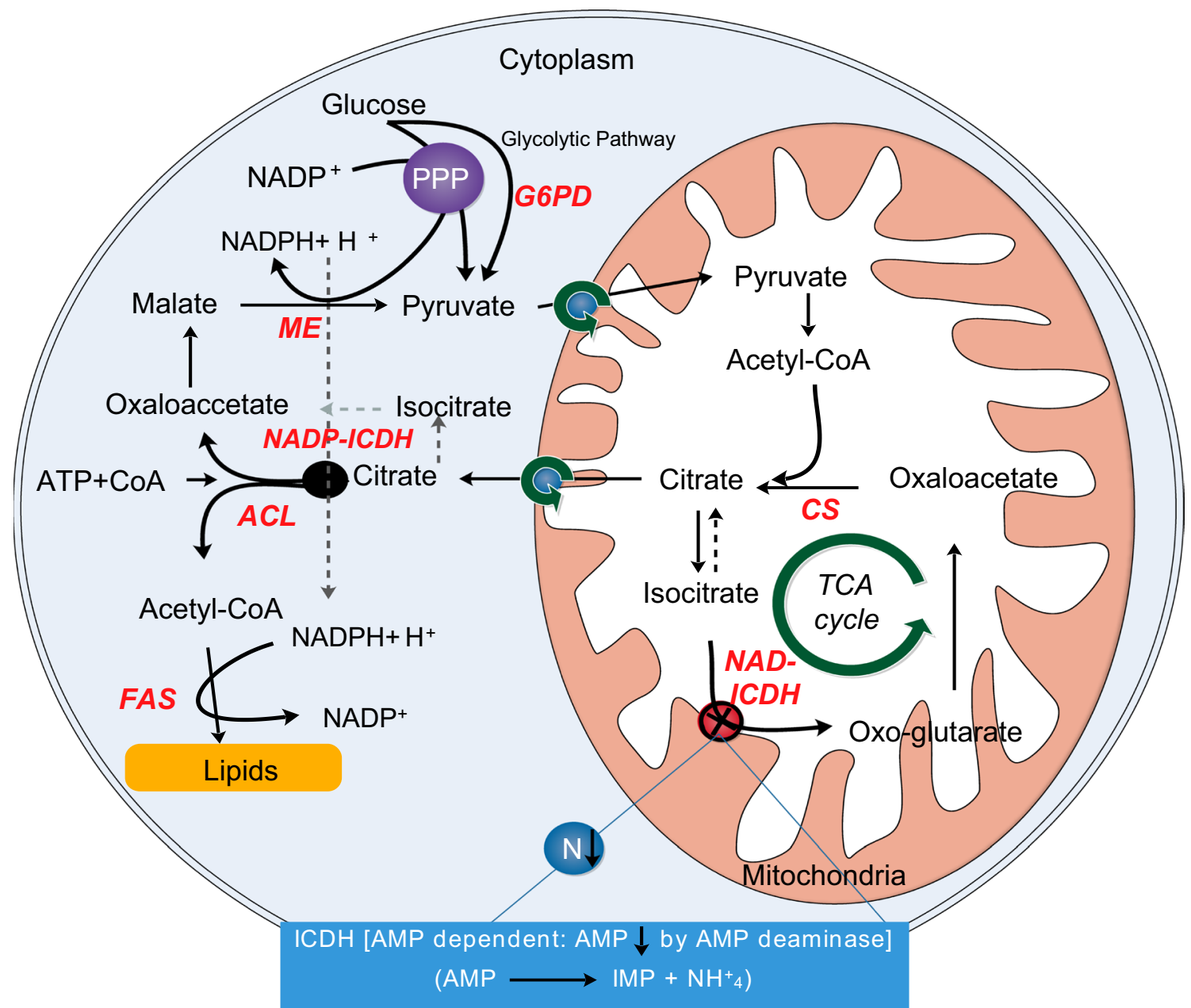

Fig. 6 Metabolic pathway of lipid accumulation in oleaginous microorganisms and related key enzymes. G6PD glucose-6-phosphate dehydrogenase, CS citrate synthase, NAD ${ }^{+}-I C D H$ NAD dependent isocitrate dehydrogenase, NADP+-ICDH NADP dependent isocitrate dehydrogenase, ACL ATP-citrate lyase, ME malic enzyme, FAS fatty acid synthase, PPP pentose phosphate pathway, AMP adenosine monophosphate, IMP inosine monophosphate

$\mathrm{NADP}^{+}-\mathrm{ICDH}$ was less active in lower nitrate concentrations than higher (Table 4). In contrast, $\mathrm{NAD}^{+}-\mathrm{ICDH}$ activity was remained consistent throughout the cultivation period under respective nitrogen treatments except $\mathrm{NaNO}_{3}$. This indicated that $\mathrm{N}$ in the form of ammonium is preferred over nitrate and somehow still present in the culture medium during the entire growth (Table 3 , $P<0.05)$. However, in case of $\mathrm{NaNO}_{3}$, a considerable decline (53.9\%) was observed from growth stage to lipid accumulation stage perhaps due to unavailability of $\mathrm{N}$ in the form of ammonium. Alternatively, when comparing different $\mathrm{N}$-sources, the activity of $\mathrm{NAD}^{+}-\mathrm{ICDH}$ in $\mathrm{NaNO}_{3}$ supplemented culture was significantly lower $(100 \%)$ than that in $\left(\mathrm{NH}_{4}\right)_{2} \mathrm{SO}_{4}$. Nevertheless, $\mathrm{NAD}^{+}-\mathrm{ICDH}$ activity increased radically with increase in $\mathrm{NaNO}_{3}$ concentration from 0.2 to $0.8 \mathrm{~g} / \mathrm{L}$ and then a slight decrease in 1.2 and $1.6 \mathrm{~g} / \mathrm{L}$ was observed (Table 4).

\section{Discussion}

Lipid accumulation in oleaginous microorganisms is a dynamic process which depends on the growth conditions (like nutrients, temperature, $\mathrm{pH}$, aeration and light in autotrophs) and growth stages. Therefore, for efficient lipid production, a proper selection of culture conditions and harvesting time are essential. The most commonly reported factor is nitrogen which showed significant effect on growth and lipid accumulation of in different microalgae (Ikaran et al. 2015; Khan et al. 2017; Lin and Lin 2011; Lin et al. 2017; Liu et al. 2016a, b; PortugalNunes et al. 2017). In present work we used different nitrogen sources and concentrations to improve algal 
Table 3 Comparison of the activity of key enzymes ( $\mathrm{nmol} / \mathrm{min} \mathbf{m g}$ protein) related to lipid accumulation in C. Cohnii at three growth stages under different $\mathrm{N}$-sources

\begin{tabular}{|c|c|c|c|c|c|c|c|c|}
\hline \multirow[t]{2}{*}{ N-sources } & \multirow[t]{2}{*}{ Growth stages } & \multicolumn{7}{|c|}{ Activity of key enzymes ( $\mathrm{nmol} / \mathrm{min} \mathrm{mg}$ protein) } \\
\hline & & FAS & ME & $\mathrm{ACL}$ & G6PD & NADP-ICDH & CS & NAD-ICDH \\
\hline \multirow[t]{3}{*}{$\left(\mathrm{NH}_{4}\right)_{2} \mathrm{SO}_{4}$} & Growth & $129.1 \pm 4.2$ & $40.5 \pm 2.9$ & $27.9 \pm 6.2$ & $252.1 \pm 3.7$ & $498.1 \pm 1.9$ & $1613.4 \pm 21.6$ & $248.4 \pm 2.1$ \\
\hline & Lipid accumulation & $138.6 \pm 1.9$ & $22.5 \pm 6.5$ & $52.2 \pm 7.3$ & $238.9 \pm 1.6$ & $417.3 \pm 3.7$ & $1428.1 \pm 13.2$ & $235.9 \pm 15$ \\
\hline & Lipid turnover & $125.9 \pm 3.8$ & $17.9 \pm 2.4$ & $18.6 \pm 1.7$ & $113.7 \pm 6.1$ & $331.6 \pm 1.6$ & $1341.7 \pm 22.7$ & $218.5 \pm 2.2$ \\
\hline \multirow[t]{3}{*}{$\mathrm{NH}_{4} \mathrm{HCO}_{3}$} & Growth & $127.6 \pm 6.1$ & $41.5 \pm 4.1$ & $26.5 \pm 2.5$ & $253.7 \pm 2.4$ & $495.9 \pm 3.9$ & $1602.5 \pm 31.8$ & $247.5 \pm 2.5$ \\
\hline & Lipid accumulation & $138.2 \pm 2.4$ & $24.7 \pm 3.8$ & $52.4 \pm 1.8$ & $242.1 \pm 1.8$ & $407.2 \pm 5.2$ & $1398.7 \pm 21.9$ & $231.7 \pm 5.2$ \\
\hline & Lipid turnover & $125.5 \pm 7.2$ & $17.2 \pm 3.4$ & $19.1 \pm 3.2$ & $113.2 \pm 2.5$ & $328.6 \pm 1.5$ & $1356.2 \pm 43.5$ & $213.6 \pm 9.2$ \\
\hline \multirow[t]{3}{*}{$\left(\mathrm{NH}_{2}\right)_{2} \mathrm{CO}$} & Growth & $140.2 \pm 2.7$ & $45.7 \pm 3.6$ & $34.4 \pm 1.9$ & $241.5 \pm 2.8$ & $382.4 \pm 7.4$ & $1705.5 \pm 23.38$ & $198.5 \pm 1.5$ \\
\hline & Lipid accumulation & $146.7 \pm 11.9$ & $34.2 \pm 5.2$ & $59.1 \pm 2.8$ & $239.3 \pm 4.6$ & $349.5 \pm 1.8$ & $1581.6 \pm 32.8$ & $194.6 \pm 3.5$ \\
\hline & Lipid turnover & $130.9 \pm 4.05$ & $21.5 \pm 1.9$ & $22.2 \pm 1.6$ & $207.5 \pm 1.9$ & $364.9 \pm 2.6$ & $1520.5 \pm 45.2$ & $189.1 \pm 1.5$ \\
\hline \multirow[t]{3}{*}{$\mathrm{NaNO}_{3}$} & Growth & $141.9 \pm 7.1$ & $56.9 \pm 6.5$ & $40.5 \pm 2.5$ & $469.4 \pm 1.2$ & $253.9 \pm 2.7$ & $1491.4 \pm 22.9$ & $127.5 \pm 3.1$ \\
\hline & Lipid accumulation & $153.5 \pm 5.9$ & $41.7 \pm 7.5$ & $72.8 \pm 3.5$ & $461.9 \pm 3.6$ & $168.6 \pm 8.9$ & $1325.7 \pm 21.7$ & $82.8 \pm 1.5$ \\
\hline & Lipid turnover & $139.2 \pm 5.6$ & $29.4 \pm 4.7$ & $36.6 \pm 4.5$ & $331.8 \pm 3.8$ & $159.1 \pm 3.4$ & $1258.2 \pm 12.8$ & $103.4 \pm 1.5$ \\
\hline
\end{tabular}

All experiments were performed in triplicate. The data presented here is mean \pm SD

G6PD glucose-6-phosphate dehydrogenase, $C S$ : citrate synthase, $N A D^{+}-I C D H$ NAD dependent isocitrate dehydrogenase, $N A D P^{+}-I C D H N A D P$ dependent isocitrate dehydrogenase, $A C L$ ATP-citrate lyase, ME malic enzyme, FAS fatty acid synthase

Table 4 Comparison of the activity of key enzymes (nmol/min $\mathbf{m g}$ protein) related to lipid accumulation in C. Cohnii at three growth stages under different $\mathrm{N}$-sources

\begin{tabular}{|c|c|c|c|c|c|c|c|c|}
\hline \multirow[t]{2}{*}{$\mathrm{NaNO}_{3}$ conc. } & \multirow[t]{2}{*}{ Growth phase } & \multicolumn{7}{|c|}{ Activity of key enzymes ( $\mathrm{nmol} / \mathrm{min} \mathrm{mg}$ protein) } \\
\hline & & ME & $A C L$ & FAS & G6PD & NADP-ICDH & CS & NAD-ICDH \\
\hline \multirow[t]{3}{*}{$0.2 \mathrm{~g} / \mathrm{L}$} & Growth & $58.7 \pm 4.7$ & $47.5 \pm 4.7$ & $152.1 \pm 1.8$ & $552.4 \pm 1.5$ & $168.4 \pm 3.7$ & $1483.8 \pm 41.8$ & $121.5 \pm 2.9$ \\
\hline & Lipid accumulation & $59.1 \pm 7.2$ & $85.9 \pm 2.8$ & $168.2 \pm 5.7$ & $638.5 \pm 2.4$ & $87.7 \pm 6.8$ & $1428.1 \pm 22.5$ & $58.1 \pm 1.8$ \\
\hline & Lipid turnover & $29.5 \pm 3.9$ & $43.6 \pm 3.9$ & $128.3 \pm 9.5$ & $413.1 \pm 3.7$ & $71.6 \pm 2.9$ & $1344.5 \pm 13.9$ & $53.9 \pm 2.5$ \\
\hline \multirow[t]{3}{*}{$0.4 \mathrm{~g} / \mathrm{L}$} & Growth & $56.9 \pm 6.5$ & $40.5 \pm 2.5$ & $141.9 \pm 2.1$ & $469.4 \pm 1.2$ & $253.9 \pm 2.71$ & $1491.4 \pm 22.5$ & $127.5 \pm 3.6$ \\
\hline & Lipid accumulation & $41.7 \pm 7.5$ & $72.8 \pm 3.1$ & $153.5 \pm 5.9$ & $461.9 \pm 3.6$ & $168.6 \pm 8.9$ & $1325.7 \pm 21.7$ & $82.8 \pm 1.5$ \\
\hline & Lipid turnover & $29.4 \pm 4.7$ & $36.6 \pm 4.5$ & $139.2 \pm 5.6$ & $331.8 \pm 3.8$ & $159.1 \pm 3.4$ & $1258.2 \pm 12.3$ & $103.4 \pm 1.5$ \\
\hline \multirow[t]{3}{*}{$0.8 \mathrm{~g} / \mathrm{L}$} & Growth & $47.8 \pm 8.5$ & $30.8 \pm 2.4$ & $146.8 \pm 3.9$ & $421.8 \pm 1.8$ & $264.9 \pm 4.9$ & $1505.9 \pm 13.1$ & $135.3 \pm 2.8$ \\
\hline & Lipid accumulation & $35.9 \pm 5.4$ & $62.1 \pm 1.9$ & $146.9 \pm 4.2$ & $471.5 \pm 1.2$ & $269.5 \pm 9.5$ & $1381.3 \pm 21.7$ & $129.7 \pm 1.5$ \\
\hline & Lipid turnover & $23.2 \pm 2.9$ & $38.5 \pm 1.9$ & $125.2 \pm 6.3$ & $398.1 \pm 1.6$ & $266.2 \pm 1.6$ & $1350.5 \pm 31.4$ & $126.2 \pm 4.7$ \\
\hline \multirow[t]{3}{*}{$1.2 \mathrm{~g} / \mathrm{L}$} & Growth & $39.9 \pm 2.6$ & $28.9 \pm 3.5$ & $139.5 \pm 2.1$ & $413.6 \pm 3.1$ & $253.9 \pm 2.6$ & $1479.2 \pm 25.5$ & $131.5 \pm 3.9$ \\
\hline & Lipid accumulation & $31.7 \pm 4.7$ & $56.2 \pm 7.4$ & $141.5 \pm 2.5$ & $385.9 \pm 2.6$ & $168.6 \pm 2.5$ & $1415.5 \pm 42.2$ & $129.8 \pm 1.9$ \\
\hline & Lipid turnover & $27.5 \pm 1.2$ & $33.5 \pm 5.2$ & $133.9 \pm 5.5$ & $372.4 \pm 1.4$ & $159.1 \pm 10.8$ & $1378.4 \pm 23.2$ & $127.9 \pm 4.5$ \\
\hline \multirow[t]{3}{*}{$1.6 \mathrm{~g} / \mathrm{L}$} & Growth & $38.5 \pm 2.8$ & $26.5 \pm 2.8$ & $132.7 \pm 2.5$ & $292.7 \pm 1.8$ & $253.9 \pm 1.8$ & $1461.4 \pm 31.5$ & $128.6 \pm 2.5$ \\
\hline & Lipid accumulation & $33.8 \pm 3.9$ & $51.1 \pm 2.4$ & $127.9 \pm 1.8$ & $264.1 \pm 2.5$ & $168.6 \pm 8.7$ & $1409.7 \pm 23.3$ & $117.1 \pm 2.5$ \\
\hline & Lipid turnover & $27.1 \pm 6.5$ & $24.9 \pm 2.71$ & $130.5 \pm 1.6$ & $227.5 \pm 3.2$ & $159.1 \pm 3.7$ & $1388.5 \pm 12.5$ & $117.9 \pm 3.8$ \\
\hline
\end{tabular}

All experiments were performed in triplicate. The data presented here is mean $\pm S D$

G6PD glucose-6-phosphate dehydrogenase, $C S$ citrate synthase, $N A D^{+}-I C D H$ NAD dependent isocitrate dehydrogenase, $N A D P^{+}-I C D H$ NADP dependent isocitrate dehydrogenase, $A C L$ ATP-citrate lyase, $M E$ malic enzyme, FAS fatty acid synthase

growth, lipid production and especially DHA production. Our results prove that $C$. cohnii grow better on nitrate $\left(\mathrm{NaNO}_{3}\right)$ than other ammonium or urea sources. Similar results were found in Scenedesmus bijugatus when cultured on six different $\mathrm{N}$-sources over 18 days in which $\mathrm{NaNO}_{3}$ had shown better growth over other $\mathrm{N}$-sources
(Arumugam et al. 2013). In contrast, S. rubescens grow faster under ammonium than other nitrogen source treatments including urea during first 5 days of culture (Lin and Lin 2011).

It has been documented that high lipid content is usually accompanied by lower growth rates under different 
stresses which often lead to decreased biomass and hence overall lipid productivity (Dhup and Dhawan 2014; Mandotra et al. 2016). However as lipid biosynthesis in C. cohnii does not follow this usual pattern, and continue to accumulate regardless of LN or HN. Ultimately, highest lipid and DHA productivity was attained with $\mathrm{NaNO}_{3}$ supplementation. In another report, highest biomass productivity was obtained in S. rubescens when treated with urea and $\mathrm{NaNO}_{3}$ mixture while highest lipid productivity was gained with ammonium treatment (Lin and Lin 2011). Similarly, T. pseudonana (Griffiths and Harrison 2009), N. oleoabundans ( $\mathrm{Li}$ et al. 2008), S. costatum (Rodolfi et al. 2008) and S. dimorphous (Benider et al. 2001) also significantly respond to different nitrogen sources. In another report, the highest biomass $(5.03 \mathrm{~g} / \mathrm{L})$, TFA $(24.9 \% \mathrm{DCW})$ and DHA contents $(82.8 \mathrm{mg} / \mathrm{g})$ of Crypthecodinium sp. SUN were achieved at $96 \mathrm{~h}$ of cultivation under light conditions (Sun et al. 2017). Under sesamol supplementation, highest biomass $(3.9 \mathrm{~g} / \mathrm{L})$, TFA $(21 \% \mathrm{DCW})$, DHA $(41.3 \%$ TFA) and DHA productivity (58 $\mathrm{mg} / \mathrm{L}$ day) was attained in C. cohnii ATCC 30556 (Liu et al. 2015). Pleissner and Eriksen (2012) reported highest biomass (2.1 g/L), TFA $(111 \mathrm{mg} / \mathrm{g})$ and DHA contents (36.2\% TFA) in C. cohnii CCMP 316 when cultured on acetic acid as major carbon source. In the present study highest biomass $(23.7 \mathrm{~g} / \mathrm{L})$, TFA (26.9\% DCW), DHA (0.99 g/L) and DHA productivity $(236 \mathrm{mg} / \mathrm{L}$ day) was attained in C. cohnii ATCC 30555 under $\mathrm{NaNO}_{3}$ supplementation. These results indicated that there is still much room to enhance lipid (\% DCW) and DHA (\% TFA) content in C. cohnii ATCC 30555.

Due to substrates depletion in lipid turnover stage, algae survived on subsequent expenditure of the reserved lipids. In fact, reserved lipid turnover commonly happened after transition from carbon excess to carbon starved conditions (Chang et al. 2013). Afterwards, net lipid productivity and lipid yield also declined. Collectively, biomass and lipid productivity confirmed a clear categorization of three different growth stages and our results present first report on identifying the three growth stages in C. Cohnii during the entire cultivation time. Thus, it can be concluded that most of the lipids were accumulated between 48 and $120 \mathrm{~h}$.

It is assumed that when $\mathrm{N}$ is limited in the medium, proteins and other $\mathrm{N}$-rich compounds are broken and used as nitrogen cell reservoir to support time-restricted growth processes (Ikaran et al. 2015). Thus, the recycling of cellular components could explain the biomass increase occurred in LN treatments. However, low final biomass content drastically reduced the overall productivity of the cell. On the other hand, higher nitrogen concentrations become toxic for algal survival. As previously stated, this is because of increased nitrate reductase activity at higher concentrations of $\mathrm{NaNO}_{3}$ leading to enhanced production of nitrite and ammonia that are accumulated in vivo (Dhup and Dhawan 2014). These accumulated nitrites and ammonia might act as toxins, resulting in decreased biomass production. Therefore, for higher biomass and lipid productivity can only achieved at MN concentration. These results were in consistent with the finding of Kim et al. (2016) and Lin and Lin (2011) that high biomass productivity can be attained at optimum $\mathrm{N}$ concentrations.

Our results also indicate that $\mathrm{N}$-source greatly affects DHA content of C. cohnii; however, there was no significant influence on $\mathrm{C} 16-\mathrm{C} 18$ content. The content of C16-C18 series of $C$. cohnii was significantly $(P<0.05)$ lower as compared to Chlorella vulgaris (Converti et al. 2009) Haematococcus pluvialis (Damiani et al. 2010) and S. rubescens (Lin and Lin 2011). As, these algal species are used for biodiesel production, it was concluded that $\mathrm{N}$-source might not be very important for biodiesel production in C. cohnii.

We report, for the first time, the activity of key enzymes potentially involved in lipid accumulation of $C$. cohnii under the influence of different $\mathrm{N}$-sources. Most probably, the gradual decline in the activities of G6PDH, ME, NADP ${ }^{+}-\mathrm{ICDH}, \mathrm{CS}$ and $\mathrm{NAD}^{+}-\mathrm{ICDH}$ during cultivation time was triggered by substrate depletion particularly glucose in the culture. The activity of FAS, ME, ACL and G6PDH were significantly $(P<0.05)$ higher under $\mathrm{NaNO}_{3}$ than other $\mathrm{N}$-sources while NADP ${ }^{+}$-ICDH and $\mathrm{NAD}^{+}$-ICDH were least active. The provision of acetyl$\mathrm{CoA}$ as an essential precursor and NADPH as reducing power source are essential for lipid biosynthesis in oleaginous microorganisms. As ACL is the key enzyme involved in citrate lyses and generates Acetyl-CoA in cytoplasm, the activity of ACL is correlated with specific rate of lipid biosynthesis. Therefore, ACL is higher under $\mathrm{NaNO}_{3}$ than other $\mathrm{N}$-sources. Similar results were found in Cunninghamella sp. 2A1 (Hamid et al. 2011). In contrast, the ACL gene expression in C. vulgaris var L3 was below the detection level at 120-144 h of cultivation in N-starved cells as compared to $\mathrm{N}$-replete conditions (Ikaran et al. 2015).

Two key enzymes, ME and G6PD, were usually known to provide NADPH for lipid biosynthesis (Ren et al. 2013). Previously, numerous studies have elucidated the role of ME in NADPH supply via conversion of malate to pyruvate and proposed as rate-limiting factor for fatty acid biosynthesis (Hao et al. 2014; Li et al. 2013; Liu et al. 2013; Wynn et al. 1999). Ratledge (2014) suggested that ME cannot provide all the required NADPH for lipid biosynthesis. Therefore, other enzymes including G6PDH and NADP ${ }^{+}$-ICDH (NADPH dependent ICDH coupled with pentose phosphate pathway (PPP) reaction 
might also be responsible for NADPH supply (Fig. 6). The higher activities of $\mathrm{ME}$ and G6PDH under $\mathrm{NaNO}_{3}$ than $\left(\mathrm{NH}_{4}\right)_{2} \mathrm{SO}_{4}$ supplemented culture indicated that both enzymes are actively involved in lipid accumulation. Our results also indicated that G6PDH contributes more NADPH then ME in C. cohnii possibly through the following reactions:

\section{Glucose-6-phosphate $+\mathrm{NADP}^{+}$ \\ $\rightarrow$ 6-phosphate- $d$-glucono-1,5-lactone $+\mathrm{NADPH}$}

The role of G6PDH in NADPH supply for lipid biosynthesis was also reported in another oleaginous microalga Chlorella protothecoides (Xiong et al. 2010) and yeast Yarrowia lipolytica (Wasylenko et al. 2015). This could also suggest the involvement of G6PDH in lipogenic pathway is according to metabolic control theory that physiological changes in metabolic flux need equal changes of activity of all or many of the enzymes of pathway. Otherwise, G6PDH and ME together play a dual role in offering NADPH for lipid biosynthesis. This concept of ME together with G6PD in offering NADPH for lipogenesis might be novel in microalgae and needed to be explored.

Another NADPH-generating enzyme ICDH, present in cytosol $\left(\mathrm{NADP}^{+}-\mathrm{ICDH}\right)$ and mitochondria $\left(\mathrm{NAD}^{+}-\mathrm{ICDH}\right)$, cytosolic form of which contributes NADPH for lipid biosynthesis in some oleaginous microorganism (Tang et al. 2014). While, mitochondrial form is critically involved in regulating the intracellular carbon flow between TCA cycle and de novo lipid biogenesis pathway (Ratledge 2014). However localization of these enzymes is still unclear in C. cohnii. Our results suggested that $\mathrm{ACL}, \mathrm{G} 6 \mathrm{PD}, \mathrm{ME}, \mathrm{NADP}^{+}$-ICD were directly associated with increased lipid accumulation, the latter three were supposed to provide reducing power (NADPH) for FAS activity. It has previously been suggested that AMP is required for activation of $\mathrm{NAD}^{+}-\mathrm{ICDH}$ (Tang et al. 2015). When $\mathrm{N}$ starts depleting in the cell, AMP is deaminated by AMP deaminase to release ammonium and IMP which in turn down-regulates $\mathrm{NAD}^{+}-\mathrm{ICDH}$ activity and results in slowdown of carbon flow through TCA cycle (Fig. 6). This sequence of biochemical events creates an equilibration between isocitrate and citrate which is, later, transported to cytosol from mitochondria and subsequently cleaved by ACL into acetyl-CoA.

Furthermore, new cells proliferation discontinuation caused by $\mathrm{N}$-depletion leads to termination of structural lipid biosynthesis. However, old cells continued to assimilate carbon source (glucose) and diverted into storage lipids, eventually accelerate total lipid production in C. cohnii. Similar results were found in Scenedesmus rubescens (Lin and Lin 2011), Schizochytrium sp.
S31 (Chang et al. 2013), C. Vulgaris var. L3 (Ikaran et al. 2015), Nannochloropsis salina (Fakhry and El Maghraby 2015) and Chlorella sp. (Ördög et al. 2016). Conclusively, lipogenic enzymes ACL, G6PD, ME, NADP ${ }^{+}$-ICD and $\mathrm{NAD}^{+}-\mathrm{ICDH}$, were shown to be vital in fatty acid biosynthesis of C. cohnii. The former three were up-regulated while later two were down-regulated in high lipid accumulation conditions via down-regulating glycolytic pathway and channelling carbon flux to elevated lipid production; when $\mathrm{NaNO}_{3}$ was provided as $\mathrm{N}$-source at lower concentration.

In conclusion, lipid accumulation in oleaginous microorganisms is a dynamic process which depends on the growth conditions and growth phases. The present study showed that $\mathrm{N}$-source and concentrations have great influence on growth and lipid accumulation. Three-way ANOVA also revealed significant differences between $\mathrm{N}$-source, N-concentration and time for biomass $(\mathrm{g} / \mathrm{L})$ and total lipid content $(\mathrm{g} / \mathrm{L})$ in the culture of $C$. cohnii $(P<0.05$; data not shown). Growth of $C$. cohnii was categorized in three distinct stages. $\mathrm{N}$-concentrations did not influence lipid and DHA content of C. cohnii, however, for higher productivity optimal N-concentration $\left(0.8 \mathrm{~g} / \mathrm{L} \mathrm{NaNO}_{3}\right)$ proven to be the best. Therefore, lipid accumulation in C. cohnii could be considered as growth-associated process in stipulations of overall productivity. Presence of more than $50-60 \%$ of $\mathrm{C} 16-\mathrm{C} 18$ content in TFA suggested that C. cohnii can also be considered as potential source for biodiesel production. Lipogenic enzymes; ACL, G6PD, ME, NADP-ICD and $\mathrm{NAD}^{+}-\mathrm{ICDH}$, were significantly responsive to $\mathrm{N}$ in growth stages and vital in fatty acid biosynthesis of $C$. cohnii. G6PDH coupled with pentose phosphate pathway (PPP), ME and/or ICDH (NADPH dependent) reaction were responsible for NADPH supply for lipid biosynthesis. This information will provide new research directions for lipid and DHA enhancement in C. cohnii in less time and cost effective manner.

\section{Abbreviations}

DCW: dry cell weight; TL: total lipid; TFA: total fatty acid; DHA: docosahexaenoic acid; LN: low nitrogen; MN: medium nitrogen; HN: high nitrogen; FAS: fatty acid synthase; ME: malic enzyme; ACL: ATP:citrate lyase; G6PDH: glucose-6-phosphate dehydrogenase; CS: citrate synthase; $\mathrm{NADP}^{+}{ }_{-} \mid \mathrm{CDH}$ : $\mathrm{NADP}^{+}$-dependent isocitrate dehydrogenase; $\mathrm{NAD}^{+}-\mathrm{ICDH}_{\mathrm{N}} \mathrm{NAD}^{+}$-dependent isocitrate dehydrogenase; PPP: pentose phosphate pathway; AMP: adenosine monophosphate; IMP: inosine monophosphate.

\section{Authors' contributions}

WS and YS designed the experiments. WS and XZ performed the experiments. WS, JH, HRS and MS analyzed the results. WS, MS and YS drafted the manuscript. All authors read and approved the final manuscript.

\section{Author details}

${ }^{1}$ State Key Laboratory of Food Science \& Technology, School of Food Science \& Technology, Jiangnan University, Wuxi 214122, Jiangsu, People's Republic of China. ${ }^{2}$ Colin Ratledge Center for Microbial Lipids, School of Agriculture 
Engineering and Food Science, Shandong University of Technology, Zibo 255049, Shandong, People's Republic of China.

\section{Acknowledgements}

This work was supported China Government Scholarship Council and the National Natural Science Foundation of China (Nos. 31271812 and 31670064).

\section{Competing interests}

The authors declare that they have no competing interests.

\section{Availability of data and materials}

The datasets supporting the conclusions of this article are included within the article.

\section{Ethics approval and consent to participate}

This article does not contain any studies with human participants or animals performed by any of the authors.

\section{Funding}

The function was provided by the National Natural Science Foundation of China (Nos. 31271812 and 31670064), National High Technology Research and Development Program of China (863 Program No. 2012AA022105C).

\section{Publisher's Note}

Springer Nature remains neutral with regard to jurisdictional claims in published maps and institutional affiliations.

Received: 2 March 2017 Accepted: 6 April 2017

Published online: 20 April 2017

\section{References}

Arumugam M, Agarwal A, Arya MC, Ahmed Z (2013) Influence of nitrogen sources on biomass productivity of microalgae Scenedesmus bijugatus. Bioresour Technol 131:246-249

Benider A, Tahiri M, Belkoura M, Dauta A (2001) Interacting effect of heliothermic factors on the growth rate of 3 Scenedesmus species. Int I Limnol 37:257-266

Bligh EG, Dyer WJ (1959) A rapid method of total lipid extraction and purification. Can J Biochem Physiol 37:911-917

Chaney AL, Marbach EP (1962) Modified reagents for determination of urea and ammonia. Clin Chem 8:130-132

Chang G, Luo Z, Gu S, Wu Q, Chang M, Wang X (2013) Fatty acid shifts and metabolic activity changes of Schizochytrium sp. S31 cultured on glycerol. Bioresour Technol 142:255-260

Collos Y, Mornet F, Sciandra A, Waser N, Larson A, Harrison PJ (1999) An opticalmethod for the rapid measurement of micromolar concentrations of nitrate inmarine phy-toplankton cultures. Pure Appl Chem 11:179-184

Converti A, Casazza AA, Ortiz EY, Perego P, Del Borghi M (2009) Effect of temperature and nitrogen concentration on the growth and lipid content of Nannochloropsis oculata and Chlorella vulgaris for biodiesel production. Chem Eng Proc 48:1146-1151

Damiani MC, Popovich CA, Constenla D, Leonardi PI (2010) Lipid analysis in Haematococcus pluvialis to assess its potential use as a biodiesel feedstock. Bioresour Technol 101:3801-3807

DeSwaaf ME, Sijtsma L, Pronk JT (2003) High-cell-density fed-batch cultivation of the docosahexaenoic acid producing marine alga Crypthecodinium cohnii. Biotechnol Bioeng 81:666-672

Dhup S, Dhawan V (2014) Effect of nitrogen concentration on lipid productivity and fatty acid composition of Monoraphidium sp. Bioresour Technol 152:572-575

Fakhry EM, El Maghraby DM (2015) Lipid accumulation in response to nitrogen limitation and variation of temperature in Nannochloropsis salina. Bot Stud 56:6. doi:10.1186/s40529-015-0085-7

Gaffney M, O'Rourke R, Murphy R (2014) Manipulation of fatty acid and antioxidant profiles of the microalgae Schizochytrium sp. through flaxseed oil supplementation. Algal Res 6:195-200
Gong Y, Liu J, Jiang M, Liang Z, Jin H, Hu X, Wan X, Hu C (2015) Improvement of omega-3 docosahexaenoic acid production by marine dinoflagellate Crypthecodinium cohnii using rapeseed meal hydrolysate and waste molasses as feedstock. PLoS ONE 10(5):1-18

González-Garcinuño Á, Tabernero A, Sánchez-Álvarez JM, Martin del Valle EM Galán MA (2014) Effect of nitrogen source on growth and lipid accumulation in Scenedesmus abundans and Chlorella ellipsoidea. Bioresour Technol 173:334-341

Griffiths MJ, Harrison STL (2009) Lipid productivity as a key characteristic for choosing algal species for biodiesel production. J Appl Phycol 21:493-507

Hamid AA, Mokhtar NF, Taha EM, Omar O, Yusoff WMW (2011) The role of ATP citrate lyase, malic enzyme and fatty acid synthase in the regulation of lipid accumulation in Cunninghamella sp. 2A1. Ann Microbiol 61:463-468

Hao G, Chen H, Wang L, Gu Z, Song Y, Zhang H, Chen W, Chen YQ (2014) Role of malic enzyme during fatty acid synthesis in the oleaginous fungus Mortierella alpina. Appl Environ Microbiol 80:2672-2678

Ikaran Z, Suárez-Alvarez S, Urreta I, Castañón S (2015) The effect of nitrogen limitation on the physiology and metabolism of chlorella vulgaris var $\mathrm{L} 3$. Algal 10:134-144

Khan MI, Lee MG, Shin JH, Kim JD (2017) Pretreatment optimization of the biomass of Microcystis aeruginosa for efficient bioethanol production. AMB Exp 7(1):19. doi:10.1186/s13568-016-0320-y

Kim G, Mujtaba G, Lee K (2016) Effects of nitrogen sources on cell growth and biochemical composition of marine chlorophyte Tetraselmis sp. for lipid production. Algae 31(3):257-266

Li Y, Horsman M, Wang B, Wu N, Lan CQ (2008) Effects of nitrogen sources on cell growth and lipid accumulation of green alga Neochloris oleoabundans. Appl Microbiol Biotechnol 81:629-636

Li Z, Sun H, Mo X, Li X, Xu B, Tian P (2013) Overexpression of malic enzyme (ME) of Mucor circinelloides im-proved lipid accumulation in engineered Rhodotorula glutinis. Appl Microbiol Biotechnol 97:4927-4936

Lin Q, Lin J (2011) Effects of nitrogen source and concentration on biomass and oil production of a Scenedesmus rubescens like microalga. Bioresour Technol 102:1615-1621. doi:10.1016/j.biortech.2010.09.008

Lin W, Li P, Liao Z, Luo J (2017) Detoxification of ammonium to Nannochloropsis oculata and enhancement of lipid production by mixotrophic growth with acetate. Bioresour Technol 227:404-7. http://linkinghub.elsevier. com/retrieve/pii/S0960852416317710

Liu Z, Gao Y, Chen J, Imanaka T, Bao J, Hua Q (2013) Analysis of metabolic fluxes for better understanding of mechanisms related to lipid accumulation in oleaginous yeast Trichosporon cutaneum. Bioresour Technol 130:144-151

Liu B, Liu J, Sun P, Ma X, Jiang Y, Chen F (2015) Sesamol enhances cell growth and the biosynthesis and accumulation of docosahexaenoic acid in the microalga Crypthecodinium cohnii. J Agric Food Chem 63(23):5640-5645

Liu J, Vanormelingen P, Vyverman W (2016a) Fatty acid profiles of four filamentous green algae under varying culture conditions. Bioresour Technol 200:1080-1084

Liu T, Li Y, Liu F, Wang C (2016b) The enhanced lipid accumulation in oleaginous microalga by the potential continuous nitrogen-limitation (CNL) strategy. Bioresour Technol 203:150-159

Lv JM, Cheng LH, Xu XH, Zhang L, Chen HL (2010) Enhanced lipid production of Chlorella vulgaris by adjustment of cultivation conditions. Bioresour Technol 101:6797-6804. doi:10.1016/j.biortech.2010.03.120

Mandotra SK, Kumar P, Suseela MR, Nayaka S, Ramteke PW (2016) Evaluation of fatty acid profile and biodiesel properties of microalga Scenedesmus abundans under the influence of phosphorus, $\mathrm{pH}$ and light intensities. Bioresour Technol 201:222-229. doi:10.1016/j.biortech.2015.11.042

Ördög V, Stirk WA, Bálint P, Aremu AO, Okem A, Lovász C, Molnár Z, van Staden $J$ (2016) Effect of temperature and nitrogen concentration on lipid productivity and fatty acid composition in three Chlorella strains. Algal Res 16:141-149. doi:10.1016/j.algal.2016.03.001

Pleissner D, Eriksen NT (2012) Effects of phosphorous, nitrogen, and carbon limitation on biomass composition in batch and continuous flow cultures of the heterotrophic dinoflagellate Crypthecodinium cohnii. Biotechnol Bioeng 109:2005-2016

Portugal-Nunes DJ, Pawar SS, Lidén G, Gorwa-Grauslund MF (2017) Effect of nitrogen availability on the poly-3-D-hydroxybutyrate accumulation by engineered Saccharomyces cerevisiae. AMB Exp 7(1):35. doi:10.1186/ s13568-017-0335-z 
Ratledge C (2014) The role of malic enzyme as the provider of NADPH in oleaginous microorganisms: a reappraisal and unsolved problems. Biotechnol Lett 36:1557-1568. doi:10.1007/s10529-014-1532-3

Ratledge C, Wynn JP (2002) The biochemistry and molecular biology of lipid accumulation in oleaginous microorganisms. Adv Appl Microbiol 51:1-51

Ratledge C, Kanagachandran K, Anderson AJ, Grantham DJ, Stephenson JC (2001) Production of docosahexaenoic acid by Crypthecodinium cohnii grown in a $\mathrm{pH}$-auxostat culture with acetic acid as principal carbon source. Lipids 36:1241. doi:10.1007/s11745-001-0838-x

Ren LJ, Feng Y, Li J, Qu L, Huang H (2013) Impact of phosphate concentration on docosahexaenoic acid production and related enzyme activities in fermentation of Schizochytrium sp. Bioprocess Biosyst Eng 36:1177-1183

Rodolfi L, Zittelli GC, Bassi N, Padovani G, Biondi N, Bonini G, Tredici MR (2008) Microalgae for oil: strain selection, induction of lipid synthesis and outdoor mass cultivation in a low-cost photobioreactor. Biotechnol Bioeng 102:100-112

Silva HR, Prete CEC, Zambrano F, de Mello VH, Tischer CA, Andrade DS (2016) Combining glucose and sodium acetate improves the growth of Neochloris oleoabundans under mixotrophic conditions. AMB Exp 6(1):10. http://www.amb-express.com/content/6/1/10

Sun D, Zhang Z, Mao X, Wu T, Jiang Y, Liu J, Chen F (2017) Light enhanced the accumulation of total fatty acids (TFA) and docosahexaenoic acid (DHA) in a newly isolated heterotrophic microalga Crypthecodinium sp. SUN. Bioresour Technol 228:227-234

Tang X, Zhang H, Chen H, Chen YQ, Chen W, Song Y (2014) Effects of 20 standard amino acids on the growth, total fatty acids production, and
Y-linolenic acid yield in Mucor circinelloides. Curr Microbiol 69:899. doi:10.1007/s00284-014-0671-z

Tang X, Chen H, Chen YQ, Chen W, Garre V, Song Y, Ratledge C (2015) Comparison of biochemical activities between high and low lipid-producing strains of Mucor circinelloides: an explanation for the high oleaginicity of strain WJ11. PLoS ONE 10(6):e0128396

Wasylenko TM, Ahn WS, Stepahnopoulos G (2015) The oxidative pentose phosphate pathway is the primary source of NADPH for lipid overproduction from glucose in Yarrowia lipolytica. Metab Eng. doi:10.1016/j.ymben.2015

Wynn JP, Hamid AA, Ratledge C (1999) The role of malic enzyme in the regulation of lipid accumulation in filamentous fungi. Microbiology 145:1911-1917

Wynn JP, Hamid AA, Li Y, Ratledge C (2001) Biochemical events leading to the diversion of carbon into storage lipids in the oleaginous fungi Mucor circinelloides and Mortierella alpina. Microbiology 147(10):2857-2864

Wynn JP, Behrens P, Sundararajan A, Hansen J, Apt K (2005) Production of Single Cell Oils byDinoflagellates. In: Sijtsma L, Anderson AJ (eds) Single Cell Oils. 1st edn. AOCS Press, Urbana

Xiong W, Liu L, Wu C, Yang C, Wu Q (2010) 13C-tracer and gas chromatography-mass spectrometry analyses reveal metabolic flux distribution in the oleaginous microalga Chlorella protothecoides. Plant Physiol 154:1001-1011

Zhao L, Zhang H, Wang L, Chen H, Chen YQ, Chen W, Song Y (2015) 13C-metabolic flux analysis of lipid accumulation in the oleaginous fungus Mucor circinelloides. Bioresour Technol 197:23-29. doi:10.1016/j. biortech.2015.08.035

\section{Submit your manuscript to a SpringerOpen ${ }^{\circ}$ journal and benefit from:}

- Convenient online submission

- Rigorous peer review

- Immediate publication on acceptance

- Open access: articles freely available online

- High visibility within the field

- Retaining the copyright to your article

Submit your next manuscript at springeropen.com 